\title{
DRILLING, CONSTRUCTION, AND AQUIFER-TEST \\ DATA FROM WELLS 3-3307-20 AND -21, THOMPSON CORNER EXPLORATORY WELLS I AND II, \\ OAHU, HAWAII
}

U.S. GEOLOGICAL SURVEY

Open-File Report 96-422

Prepared in cooperation with the

CITY AND COUNTY OF HONOLULU BOARD OF WATER SUPPLY
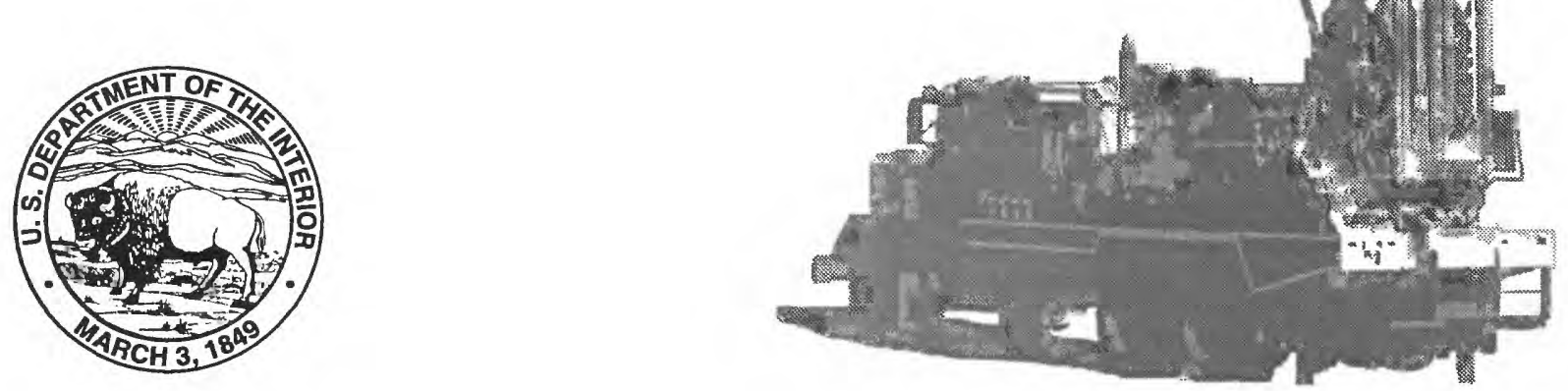


\title{
U.S. DEPARTMENT OF THE INTERIOR BRUCE BABBITT, Secretary
}

\author{
U.S. GEOLOGICAL SURVEY \\ Gordon P. Eaton, Director
}

Any use of trade, product, or firm names in this publication is for descriptive purposes only and does not imply endorsement by the U.S. Government

For sale by the

U.S. Geological Survey

Branch of Information Services

Box 25286

Denver, CO 80225-0286

For additional information write to:

District Chief

U.S. Geological Survey

677 Ala Moana Blvd., Suite 415

Honolulu, HI 96813 


\section{CONTENTS}

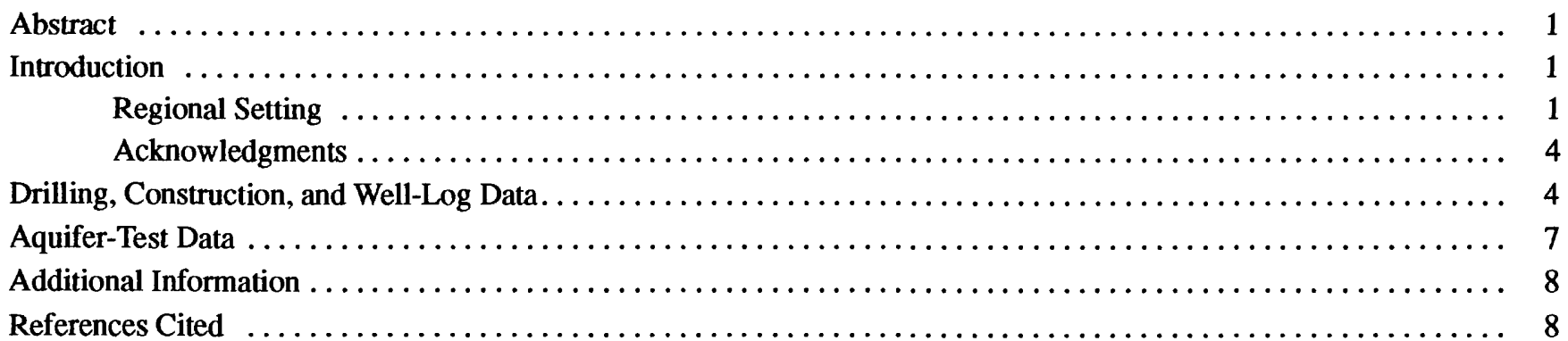

FIGURES

1-2. Maps showing:

1. Ground-water areas of north-central Oahu and wells drilled during the study, Hawaii ..........

2. Location of Thompson Corner exploratory wells I and II, Oahu, Hawaii. . . . . . . . . . . . . 3

3-4. Diagrams showing:

3. Construction details for Thompson Corner exploratory well I (State well number 3-3507-20),

Oahu, Hawaii.

4. Construction details for Thompson Corner exploratory well II (State well number 3-3507-21),

Oahu, Hawaii .

\section{TABLES}

1. Construction data for Thompson Corner exploratory well I, Oahu, Hawaii .................... 4

2. Construction data for Thompson Corner exploratory well II, Oahu, Hawaii $\ldots \ldots \ldots \ldots \ldots \ldots \ldots \ldots \ldots \ldots$

3. Geologic $\log$ for Thompson Corner exploratory well I (State well number 3-3307-20), Oahu, Hawaii . . ....... 9

4. Geologic log for Thompson Corner exploratory well II (State well number 3-3307-21), Oahu, Hawaii. . . . . . . . . 10

5. Driller's log for Thompson Corner exploratory well I (State well number 3-3307-20), Oahu, Hawaii . . . . . . . 11

6. Driller's log for Thompson Corner exploratory well II (State well number 3-3307-21), Oahu, Hawaii ........ 12

7. Water-level measurements for constant-pumping-rate aquifer test of July 28-30, 1993, Thompson

Corner wells (State well number 3-3307-20 and -21), Oahu, Hawaii. . . . . . . . . . . . . . . 13

8. Water-level measurements for constant-pumping-rate aquifer test of August 5-7, 1993, Thompson

Corner wells (State well number 3-3307-20 and -21 ), Oahu, Hawaii. . . . . . . . . . . . . . . 18

9. Water-level measurements for step-drawdown test of pumped Thompson Corner exploratory well I (State well number 3-3307-20), August 4, 1993, Oahu, Hawaii. . . . . . . . . . . . . . . 22

10. Construction data for wells drilled during the study, Oahu, Hawaii $\ldots \ldots \ldots \ldots \ldots \ldots \ldots \ldots \ldots \ldots \ldots \ldots$

\section{Conversion Factors}

\begin{tabular}{rll}
\hline Multiply & By & To obtaln \\
\hline foot $(\mathrm{ft})$ & 0.3048 & meter \\
mile (mi) & 1.609 & kilometer \\
inch (in.) & 25.4 & millimeter \\
gallon per minute $(\mathrm{gal} / \mathrm{min})$ & 0.06308 & liter per minute \\
\hline
\end{tabular}

Elevations in this report are referenced relative to mean sea level. 


\section{Drilling, Construction, and Aquifer-Test Data for Wells 3-3307-20 and -21, Thompson Corner Exploratory Wells I and II, Oahu, Hawaii}

\section{By Todd K. Presley and Delwyn S. Oki}

\section{Abstract}

The Thompson Corner exploratory wells I and II (State well numbers 3-3307-20 and -21) were drilled near Thompson Corner, about 2.2 miles south-southwest of the town of Haleiwa. The wells are located on agricultural land in the Waialua ground-water area. The wells are about 50 feet apart and penetrate about 90 feet into the ground water. Aquifer tests were conducted using well 3 3307-20 as a pumping well and well 3-3307-21 as an observation well. Well-construction data, logs of drilling notes, geologic descriptions for the samples, and aquifer-test data are presented for the wells. The wells are two of twelve exploratory wells drilled in the north-central Oahu area between July 1993 and May 1994 in cooperation with the Honolulu Board of Water Supply.

\section{INTRODUCTION}

Because of water-supply concerns associated with population increase on the island of Oahu, the Honolulu Board of Water Supply, in cooperation with the U.S. Geological Survey (USGS), conducted a study to assess the availability of ground water in north-central Oahu. This study included drilling 12 exploratory and monitoring wells between July 1993 and May 1994.

This report presents drilling, construction, well$\log$, and aquifer-test data for Thompson Comer exploratory wells I and II (State well numbers 3-3307-20 and -21 ). The wells are located along a sugar plantation road about $2.2 \mathrm{mi}$ south-southwest of the town of Haleiwa (figs. 1 and 2). The wells were constructed about $50 \mathrm{ft}$ apart. The purposes of the Thompson Comer wells were
(1) to conduct local-scale aquifer tests, and (2) to serve as observation wells for monitoring water levels near four major irrigation pumping stations. The wells v'ere drilled in the Waialua ground-water area (Rosenau and others, 1971; Dale, 1978; Hunt, in press).

\section{Regional Setting}

The study area is located in north-central Oahu between the crests of the Koolau Range and the Waianae Range (fig. 1). Summarized here are previous studies that describe the physical and geological asp:cts of the study area (Rosenau and others, 1971; Dale, 1978; Hunt, in press). The mountain ranges are the eroded remnants of two shield volcanoes, the Waianae Volcano and the Koolau Volcano. The Mokuleia ground-water area lies in the basalt aquifer of the Waianae Volcano, and the Waialua and Kawailoa ground-water area lie in the basalt aquifer of the Koolau Volcano. The Mokuleia and Waialua ground-water areas are separated by low-permeability paleosols and saprolite of the Waianae Volcano that lie below the geologic contact between the Waianae and Koolau Volcanoes. The Waialua and Kawailoa ground-water areas are separated by alluvium and weathered basalt in and beneath Anahulu Gulch. Seaward flow of ground w?ter in the Mokuleia and Waialua ground-water areas is impeded by a coastal confining unit that is composed of marine and terrestrial sediment known locally as "caprock." The caprock creates a confined artesian condition at low elevations near the shore. Further inland however, the aquifer is unconfined.

Water levels in the Waialua and Kawailoa groundwater areas are about $12 \mathrm{ft}$ and $4 \mathrm{ft}$ above mean sea level, respectively. Water levels in the Mokuleia ground-water area are about $20 \mathrm{ft}$. Withdrawal from the Waialua, Kawailoa and Mokuleia ground-water arec $\mathrm{s}$ is 


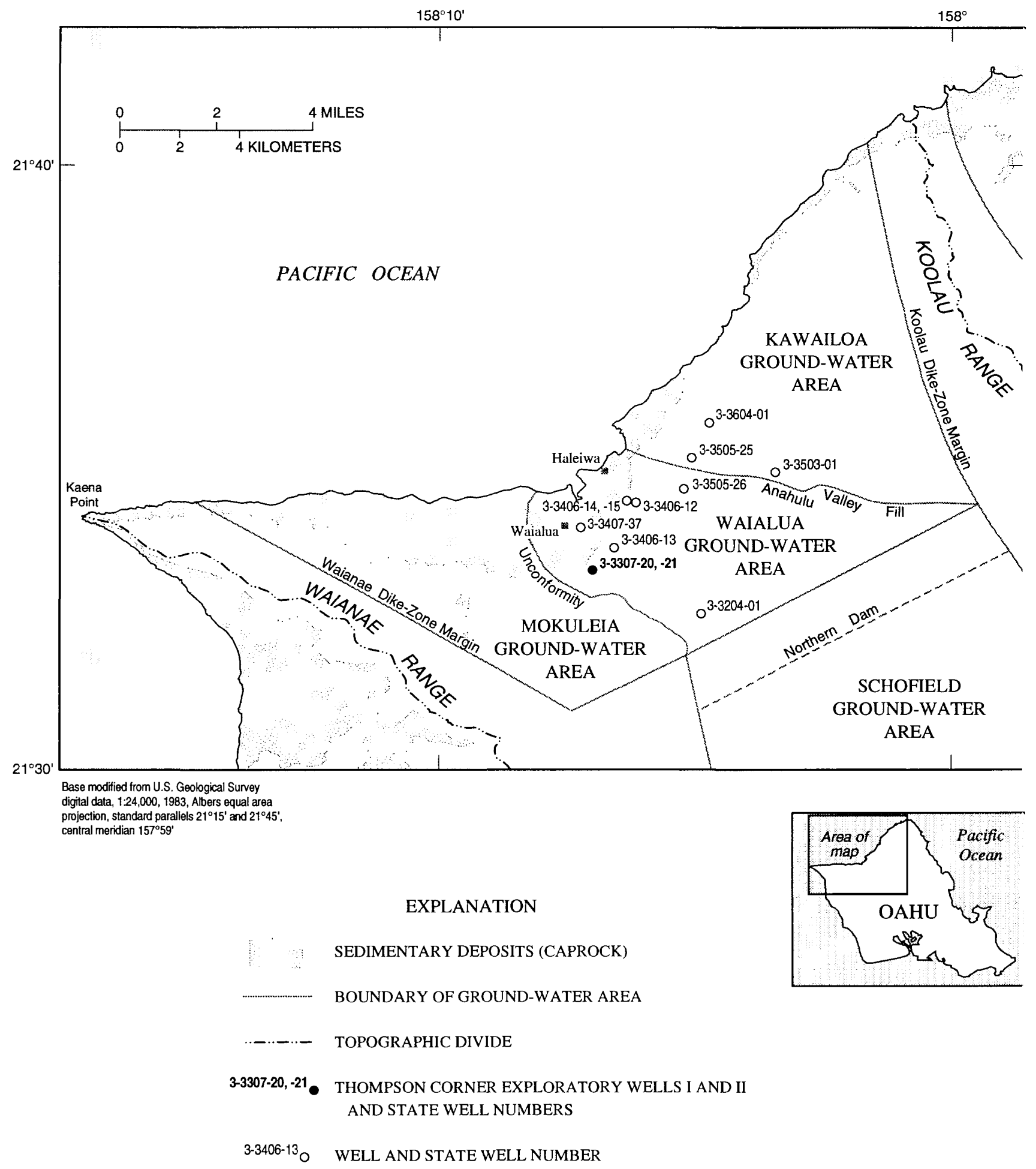

Figure 1. Ground-water areas of north-central Oahu (modified from Hunt, in press) and wells drilled during the study, Hawaii. 


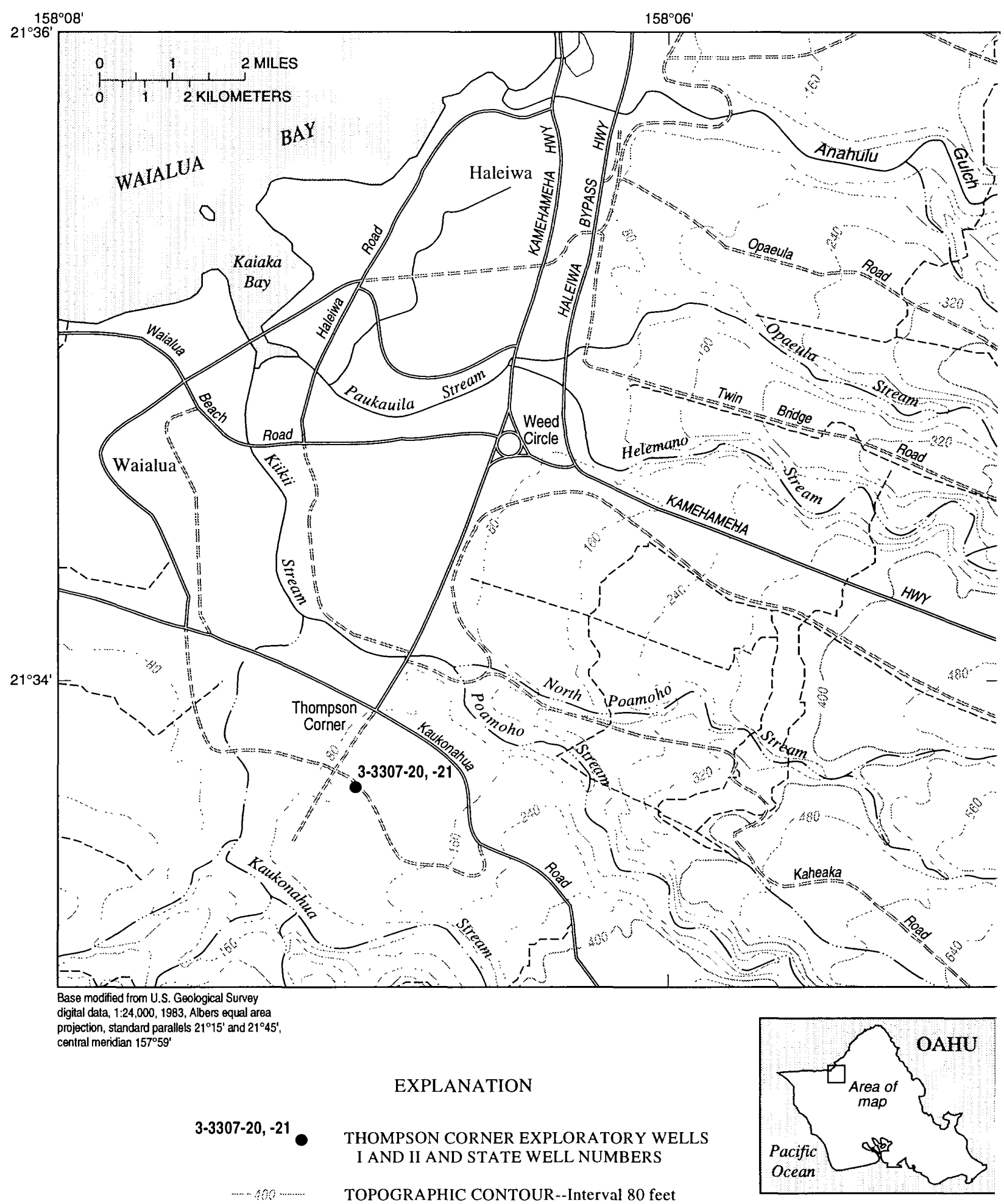

DITCH

Figure 2. Location of Thompson Corner exploratory wells I and II, Oahu, Hawaii. 
primarily for sugarcane irrigation, although there are also several municipal wells and numerous small capacity private wells. Natural ground-water discharge occurs at springs and by subsurface flow through the caprock to the ocean (Rosenau and others, 1971).

\section{Acknowledgments}

The USGS gratefully acknowledges the Waialua Sugar Company for their assistance in identifying and preparing the drill site. The USGS also thanks the Cas- tle and Cooke Land Company for permission to drill on their land.

\section{DRILLING, CONSTRUCTION, AND WELL.- LOG DATA}

Thompson Comer exploratory wells I and II are about 2,000 ft northeast of Thompson Corner along a sugarcane plantation road (fig. 2). Well-construction data is provided in tables 1 and 2 and shown in figures 3 and 4.

Table 1. Construction data for Thompson Corner exploratory well I, Oahu, Hawaii.

[Elevation datum is mean sea level; in., inch; $\mathrm{ft}$, feet; od, outside diameter]

\begin{tabular}{ll}
\hline Well name & Thompson Corner exploratory well I \\
State well number & $3-3307-20$ \\
Latitude and longitude & $21^{\circ} 33^{\prime} 41^{\prime} \mathrm{N}, 158^{\circ} 07^{\prime} 02^{\prime} \mathrm{W}$ \\
Hawaii tax map key number & $6-5-01-1$ \\
Landowner & Castle and Cooke Land Company \\
Leaseholder & Waialua Sugar Company \\
Well completed & July 9,1993 \\
Working days to complete & 14 days \\
Driller & Fred Thibedeau, USGS \\
Surface hole diameter & $171 / 2$ in. \\
Bottom of surface casing elevation & $-65 \mathrm{ft}$ \\
Surface casing diameter and type & $125 / 8$-in. od steel, 0.25 -in. wall thickness \\
Final hole diameter & $121 / 4$ in. \\
Bottom of well elevation & $-82 \mathrm{ft}$ \\
Open interval of well & $-65 \mathrm{to}-82 \mathrm{ft}$ \\
Reference mark elevation (bolt) & $99.10 \mathrm{ft}$ \\
Water level and date of measurement & $11.32 \mathrm{ft}$, August 5,1993 \\
\hline
\end{tabular}

Table 2. Construction data for Thompson Corner exploratory well II, Oahu, Hawaii. [Elevation datum is mean sea level; in., inch; $\mathrm{ft}$, feet; od, outside diameter]

\begin{tabular}{ll}
\hline Well name & Thompson Corner exploratory well II \\
State well number & $3-3307-21$ \\
Latitude and longitude & $21^{\circ} 33^{\prime} 41^{\prime \prime} \mathrm{N}, 158^{\circ} 07^{\prime} 01^{\prime \prime} \mathrm{W}$ \\
Hawaii tax map key number & $6-5-01-1$ \\
Landowner & Castle and Cooke Land Company \\
Leaseholder & Waialua Sugar Company \\
Well completed & August 9,1993 \\
Working days to complete & 15 days \\
Driller & Fred Thibedeau, USGS \\
Surface hole diameter & $121 / 4$ in. \\
Bottom of surface casing elevation & $17 \mathrm{ft}$ \\
Surface casing diameter and type & $85 / 8$-in. od steel, 0.25 -in. wall thickness \\
Final hole diameter & $77 / 8$ in. \\
Bottom of well elevation & $-80 \mathrm{ft}$ \\
Open interval elevations & $17 \mathrm{ft}$ to $-80 \mathrm{ft}$. \\
Screened interval elevations & $20 \mathrm{ft}$ to $-80 \mathrm{ft}$ \\
Inner casing diameter and type & $41 / 2$-in. od PVC, flush-jointed \\
Screen type & $41 / 2$-in. od PVC, flush-jointed, 0.02-in. horizontal slots \\
Reference mark elevation (bolt) & $99.96 \mathrm{ft}$ \\
Top of casing measuring point elevation & $101.40 \mathrm{ft}$ (top of $85 / 8$-in. steel casing) \\
Water level and date of measurement & $11.29 \mathrm{ft}$, August 5,1993 \\
\hline
\end{tabular}




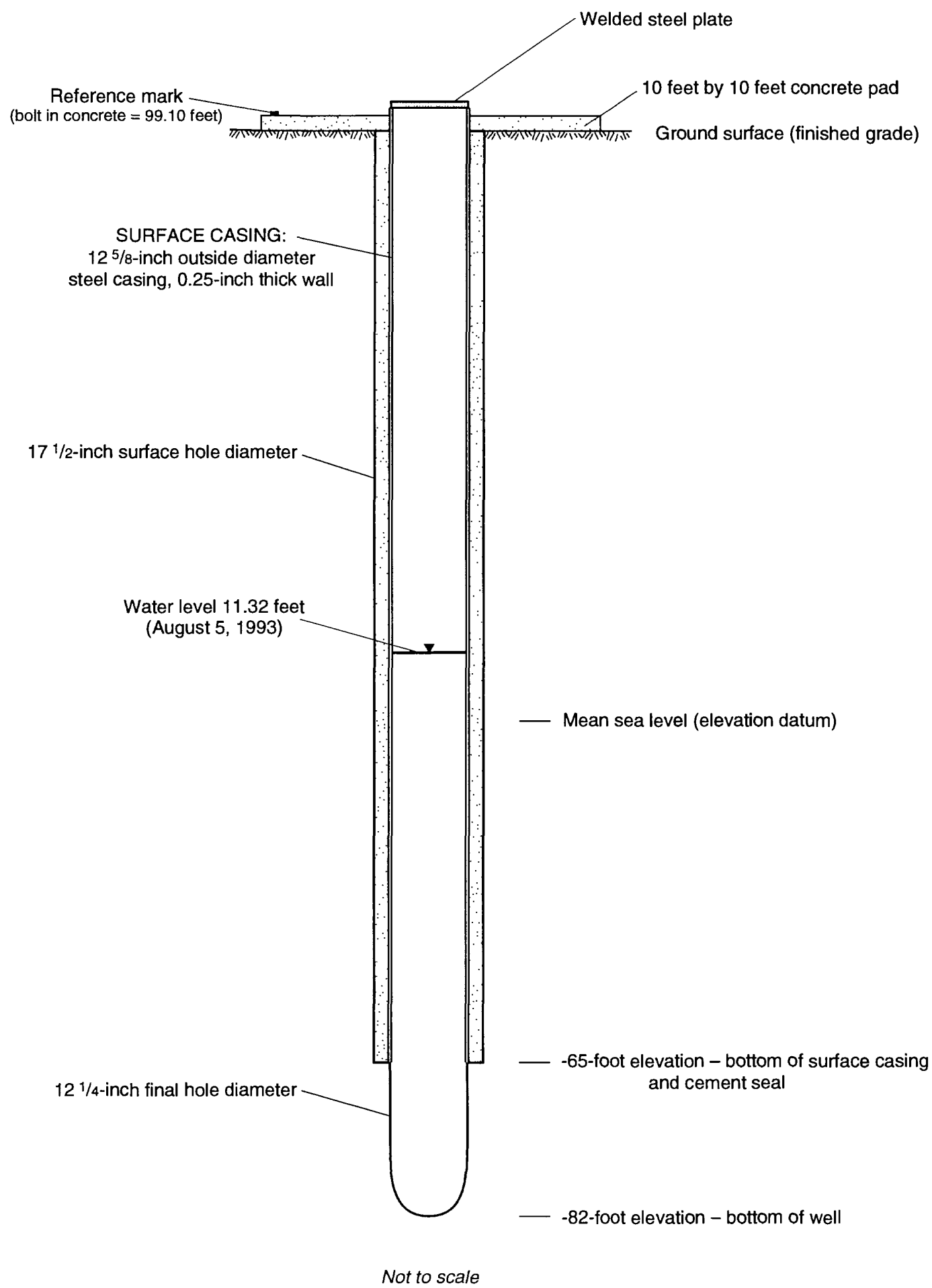

Figure 3. Construction details for Thompson Corner exploratory well I (State well number 3-3307-20), Oahu, Hawaii. 


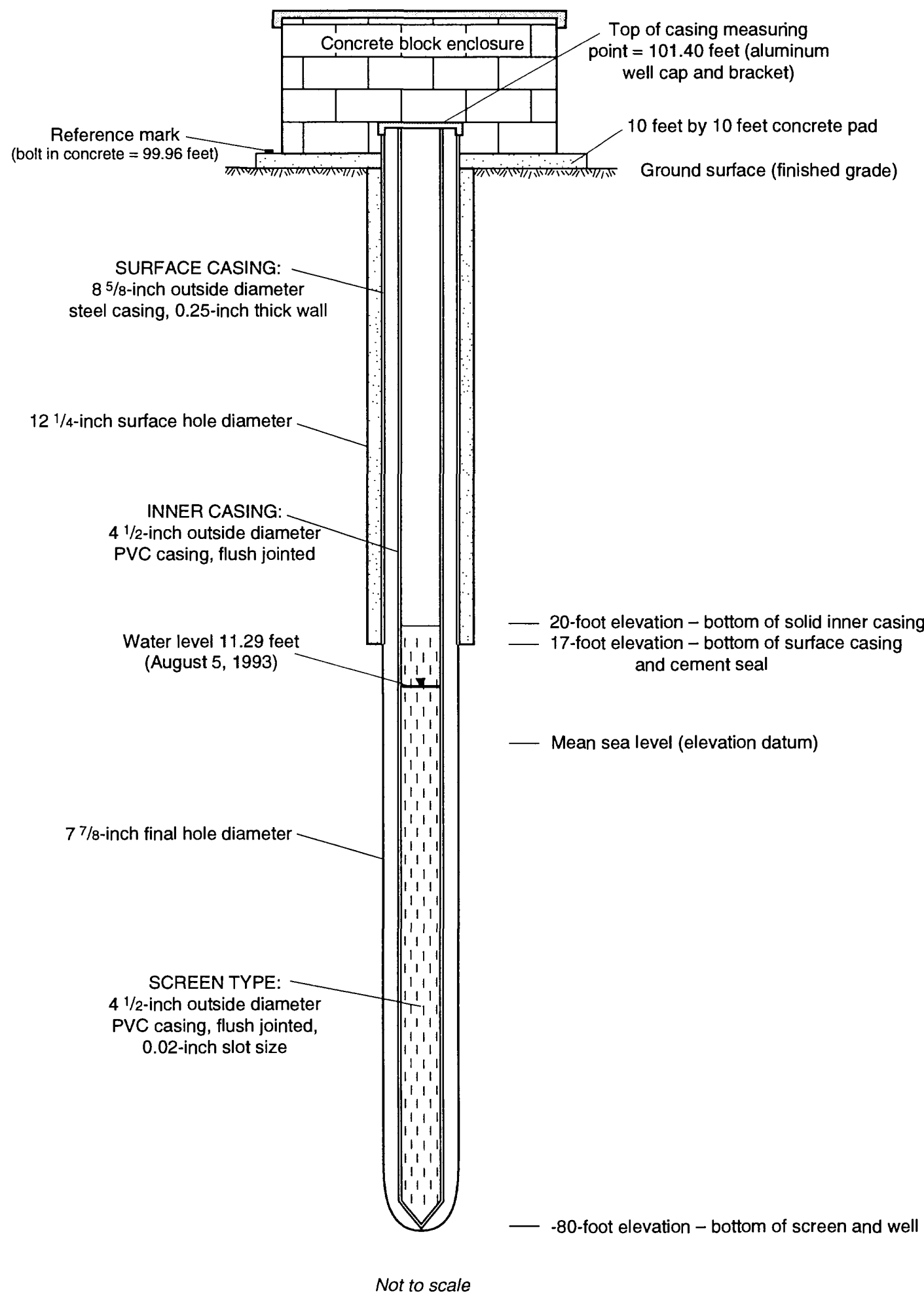

Figure 4. Construction details for Thompson Corner exploratory well II (State well number 3-3307-21), Oahu, Hawaii. 
The wells were drilled using an air-rotary drilling system with flush-jointed 4 1/2-in. diameter drill pipe. Drilling foam and polymer were injected into the aircirculation system to assist the removal of drill cuttings and to stabilize the holes.

The first well (State well number 3-3307-20) was constructed as a pumping well for aquifer tests. The well was drilled from an elevation of about $99 \mathrm{ft}$ to about $-82 \mathrm{ft}$ with an $81 / 2$-in. diameter drill bit. The hole diameter was then enlarged to $171 / 2$-in. from the surface to an elevation of $-65 \mathrm{ft}$. The well was cased with $121 / 2$-in. outside-diameter casing to the $-65 \mathrm{ft}$ elevation. The annular space between the hole and the casing was grouted with cement to provide a surface seal. The well was re-drilled with a 12-in. diameter drill bit to an elevation of $-82 \mathrm{ft}$ and left uncased. A water-producing zone of high yield was penetrated within the bottom 20 $\mathrm{ft}$ of the hole. The uncased portion, between the -65 and -82-ft elevations of the well, corresponds with the water-producing zone. An 8-in. diameter submersible pump capable of pumping about $600 \mathrm{gal} / \mathrm{min}$ was temporarily installed in the well for aquifer tests.

The second well (State well number 3-3307-21) was constructed as an observation well. The well was drilled from an elevation of about $100 \mathrm{ft}$ to about $17 \mathrm{ft}$ using a $121 / 2$-in. diameter drill bit. The well was cased with about $85 \mathrm{ft}$ of $85 / 8$-in. outside-diameter steel casing to an elevation of $17 \mathrm{ft}$, and the annular space grouted with cement. The hole was deepened using a 7 7/8-in. diameter drill bit to an elevation of about $0 \mathrm{ft}$, penetrating about $11 \mathrm{ft}$ below the water table leaving about 17 feet of open hole, and left uncased. The first of two 48-hour, constant-rate, aquifer tests was conducted. After the first test, the observation well was deepened to about the same elevation $(-80 \mathrm{ft})$ as the pumped well, leaving an open hole between the 17 and -80 -ft elevations, and left uncased for the second 48-hour aquifer test.

Samples of the materials expelled by the circulation system were collected every $5 \mathrm{ft}$. Geologic logs (geologic descriptions of the samples recovered from drilling) are listed in tables 3 and 4, and driller's logs (driller's observations while drilling) are presented in tables 5 and 6 . From the surface, both wells penetrated about $30 \mathrm{ft}$ of clay and saprolite, $45 \mathrm{ft}$ of slightly weathered basalt, and $105 \mathrm{ft}$ of primarily unweathered basalt with a few thin, reddish clay and clinker layers.
At the conclusion of the aquifer tests, the casing of the pumped well (3-3307-20) was cut to within about 2 in. of the concrete pad and a steel plate welded to the casing to prevent unwanted access. The observation well (3-3307-21) was cased with 4 1/2-in. outsidediameter flush-jointed PVC casing. The observatior well was then outfitted for long-term water-level monitoring using a data recorder.

The measuring point (elevation $101.40 \mathrm{ft}$ ) for water-level determination by measuring tape for well 3$3307-21$ is located at the top of the $85 / 8$-in. outsidediameter steel surface casing. An additional reference mark (elevation $99.96 \mathrm{ft}$.) for the well is located on the top of a stainless steel bolt emplaced in the concrete pad surrounding the well. During the aquifer tests, a tem porary measuring point (elevation $101.11 \mathrm{ft}$.) for the pumped well (3-3307-20) was established at the tof of an access tube strapped to the pump column. Because the casing of the well 3-3307-20 was cut and weldet closed, only a reference mark still remains. The reference mark (elevation $99.10 \mathrm{ft}$ ) is located at the top cf a stainless-steel bolt emplaced into the concrete pad of well 3-3307-20.

\section{AQUIFER-TEST DATA}

Three aquifer tests were conducted at the Thompson Corner site. Two 48-hour, constant-pumping-rate aquifer tests were conducted on July 28-30, 1993 and August 5-7, 1993, and a step-drawdown test was ccnducted on August 4, 1993. The two 48-hour aquifer tests were designed to help estimate the horizontal and vertical components of hydraulic conductivity in the vicirity of the test site, and the step-drawdown test was performed to determine the well loss component of the total drawdown.

The first 48-hour aquifer test was conducted with the observation well (Thompson Corner exploratory well II) drilled to an elevation of $0 \mathrm{ft}$. This configuration, where the open interval of the observation well (17 to $0 \mathrm{ft}$ elevations) is separated from the open interva ${ }^{1}$ of the pumped well ( -65 to $-82 \mathrm{ft}$ elevations) by $65 \mathrm{ft}$, allows for analysis of the vertical component of the hydraulic conductivity. At least two hard layers of rolcanic rock, assumed to be separate flow units, were encountered within the separation interval. The second 48-hour aquifer test was conducted after the observation well was deepened to an elevation of $-80 \mathrm{ft}$. The ob?er- 
vation well was uncased during both aquifer tests. Pumping rate was monitored with a totalizing flow meter and was maintained at about $610 \mathrm{gal} / \mathrm{min}$ for both constant-pumping-rate tests.

During the pumping tests, water levels were manually measured with a electric water-level probe. The manually measured data and pumping-rate observations for both aquifer tests are provided in tables 7 and 8 . Measurement data for a multiple pumping rate, stepdrawdown test are provided in table 9. In addition, vented, submersible pressure transducers connected to recording data loggers were used in both wells to provide higher resolution data (unpublished data in files of the USGS, Honolulu). The data loggers were programmed to sample at 0.5 -second intervals during the first 3 or 4 minutes of the drawdown and recovery periods. The sampling rates were subsequently increased to 1 second for the next 3 minutes, 1 minute for the next 55 minutes, and finally 10 minutes for the remainder of the tests. Multiple transducers were used for redundancy in case of transducer failure.

\section{ADDITIONAL INFORMATION}

Information for the 12 wells drilled during the north-central Oahu study is listed in table 10 . Nine of the wells, including Thompson Corner exploratory wells I and II (State well numbers 3-3307-20 and -21), were drilled in the Waialua ground-water area, and three wells were drilled north of Anahulu Gulch in the Kawailoa ground-water area. Water-level time-series data were collected for all the wells drilled and for numerous other existing wells as part of the overall monitoring effort for the project (unpublished data in files of the USGS, Honolulu). Data were collected using electronic data loggers coupled to shaft encoder-float systems or to pressure transducers.

\section{REFERENCES CITED}

Dale, R.H., 1978, A ground-water inventory of the Waialua basal-water body, island of Oahu, Hawaii: U.S. Geological Survey Open-File Report 78-24, 71 p.

Hunt, C.D., Jr., in press, Geohydrology of the island of Oahu, Hawaii: U.S. Geological Survey Professional Paper 1412-B.

Rosenau, J.C., Lubke,E.R., and Nakahara, R.H., 1971, Water resources of north-central Oahu, Hawaii: U.S. Geological Survey Water-Supply Paper 1899-D, 40 p. 
Table 3. Geologic log for Thompson Corner exploratory well I (State well number 3-3307-20), Oahu, Hawaii [Elevation datum is mean sea level]

\begin{tabular}{|c|c|c|c|}
\hline $\begin{array}{c}\text { Depth below } \\
\text { grade } \\
\text { (feet) }\end{array}$ & $\begin{array}{c}\text { Elevation } \\
\text { (feet) }\end{array}$ & Sample descriptlon & Comments \\
\hline 0 to 5 & 99 to 94 & Red clay & \\
\hline 5 to 10 & 94 to 89 & Red clay & \\
\hline 10 to 15 & 89 to 84 & Yellowish-red saprolite & \\
\hline 15 to 20 & 84 to 79 & Yellowish-red saprolite & \\
\hline 20 to 25 & 79 to 74 & Red clay & \\
\hline 25 to 30 & 74 to 69 & Grey, weathered pahoehoe & \\
\hline 30 to 35 & 69 to 64 & Reddish-grey, weathered basalt & \\
\hline 35 to 40 & 64 to 59 & Dark grey, hard, friable clay & \\
\hline 40 to 45 & 59 to 54 & Dark grey, hard, friable clay & \\
\hline 45 to 50 & 54 to 49 & Grey, lightly vesicular, weathered basalt & \\
\hline 50 to 55 & 49 to 44 & Grey basalt & Less weathered than above \\
\hline 55 to 60 & 44 to 39 & Grey, slightly vesicular basalt & \\
\hline 60 to 65 & 39 to 34 & Grey, slightly weathered pahoehoe & \\
\hline 65 to 69.5 & 34 to 29.5 & Grey, slightly weathered pahoehoe & \\
\hline 69.5 to 70 & 29.5 to 29 & Reddish, slightly weathered basalt & \\
\hline 70 to 75 & 29 to 24 & Reddish-grey, highly vesicular, slightly weathered basalt & \\
\hline 75 to 80 & 24 to 19 & Grey, unweathered, nonvesicular, massive basalt & \\
\hline 80 to 85 & 19 to 14 & Grey, unweathered, nonvesicular, massive basalt & \\
\hline 85 to 89 & 14 to 10 & Grey, unweathered, nonvesicular, massive basalt & Rare olivine \\
\hline 89 to 95 & 10 to 4 & Reddish-grey, vesicular basalt & \\
\hline 95 to 103 & 4 to -4 & Reddish-grey to red, weathered, vesicular clinker & \\
\hline 103 to 105 & -4 to -6 & Brownish-grey, hard, massive basalt & \\
\hline 105 to 110 & -6 to -11 & Brownish-grey, hard, massive basalt & \\
\hline 110 to 115 & -11 to -16 & Brownish-grey, hard, massive basalt & \\
\hline 115 to 120 & -16 to -21 & Brownish-grey, hard, massive basalt & \\
\hline 120 to 128 & -21 to -29 & Brownish-grey, hard, massive basalt & \\
\hline 128 to 130 & -29 to -31 & Red clay and clinker & \\
\hline 130 to 135 & -31 to -36 & Red clay and clinker & \\
\hline 135 to 140.5 & -36 to -41.5 & Grey, hard, unweathered basalt & Fine cuttings \\
\hline 140.5 to 143.5 & -41.5 to -44.5 & Grey, unweathered basalt & Darker than above \\
\hline 143.5 to 145 & -44.5 to -46 & Dark grey, highly vesicular, unweathered basalt & Possibly clinker \\
\hline 145 to 147.5 & -46 to -48.5 & Dark grey, hard, unweathered basalt & Very fine cuttings \\
\hline 147.5 to 153.25 & -48.5 to -54.3 & Reddish-dark grey, highly vesicular basalt & \\
\hline 153.25 to 155 & -54.3 to -56 & Reddish clay & \\
\hline 155 to 157 & -56 to -58 & Reddish-dark grey, highly vesicular basalt & \\
\hline 157 to 158.5 & -58 to -59.5 & Reddish clay & \\
\hline 158.5 to 165 & -59.5 to -66 & Grey, highly vesicular basalt & \\
\hline 165 to 168 & -66 to -69 & Grey, highly vesicular basalt & Some large cuttings \\
\hline 168 to 170 & -69 to -71 & Grey, hard, nonvesicular basalt & \\
\hline 170 to 175 & -71 to -76 & Grey, hard, vesicular and nonvesicular basalt & \\
\hline 175 to 180 & -76 to -81 & Grey, hard, vesicular and nonvesicular basalt & \\
\hline 180 & -81 & $\begin{array}{l}\text { Reddish, vesicular basalt; dark grey, massive, olivine- } \\
\text { phyric basalt }\end{array}$ & \\
\hline
\end{tabular}


Table 4. Geologic log for Thompson Corner exploratory well II (State well number 3-3307-21), Oahu, Hawaii. [Elevation datum is mean sea level]

\begin{tabular}{|c|c|c|c|}
\hline $\begin{array}{l}\text { Depth } \\
\text { (feet) }\end{array}$ & $\begin{array}{l}\text { Elovation } \\
\text { (feet) }\end{array}$ & Sample descriptlon & Comments \\
\hline 0 to 5 & 100 to 95 & Red clay & \\
\hline 5 to 10 & 95 to 90 & Red clay & \\
\hline 10 to 15 & 90 to 85 & Yellowish-red saprolite & \\
\hline 15 to 20 & 85 to 80 & Yellowish-red saprolite; light grey, weathered basalt & \\
\hline 20 to 25 & 80 to 75 & $\begin{array}{l}\text { Reddish-grey saprolite; few chunks red-grey, hard, slightly } \\
\text { vesicular basalt }\end{array}$ & \\
\hline 25 to 30 & 75 to 70 & Red clay; grey vesicular basal chips & \\
\hline 30 to 35 & 70 to 65 & $\begin{array}{l}\text { Grey, hard, slightly vesicular basalt; some reddish-brown, } \\
\text { weathered material }\end{array}$ & \\
\hline 35 to 40 & 65 to 60 & Light grey, vesicular, massive, unweathered basalt & \\
\hline 40 to 45 & 60 to 55 & Light grey, vesicular, massive, unweathered basalt & \\
\hline 45 to 50 & 55 to 50 & Grey, vesicular, massive, unweathered basalt & Darker than above \\
\hline 50 to 55 & 50 to 45 & Grey, unweathered basalt & More massive than above \\
\hline 55 to 60 & 45 to 40 & Dark grey, unweathered basalt & Similar to above \\
\hline 60 to 65 & 40 to 35 & Dark grey, unweathered basalt & Similar to above \\
\hline 65 to 70 & 35 to 30 & Dark grey, unweathered basalt & Similar to above \\
\hline 70 to 75 & 30 to 25 & $\begin{array}{l}\text { Reddish-grey saprolite; grey, unweathered, nonvesicular } \\
\text { basalt }\end{array}$ & \\
\hline 75 to 80 & 25 to 20 & Reddish-grey, highly weathered basalt & \\
\hline 80 to 85 & 20 to 15 & Grey, weathered, nonvesicular basalt & Soft \\
\hline 85 to 90 & 15 to 10 & Grey, unweathered, vesicular basalt; reddish-brown clay & \\
\hline 90 to 95 & 10 to 5 & Grey, unweathered, slightly vesicular basalt & \\
\hline 95 to 100 & 5 to 0 & Reddish, vesicular, weathered basalt & Possibly clinker \\
\hline 100 to 105 & 0 to -5 & Reddish, nonvesicular, hard basalt & Fine \\
\hline 105 to 110 & -5 to -10 & Dark grey, massive, hard basalt & \\
\hline 110 to 115 & -10 to -15 & Dark grey, massive, hard basalt & Darker than above \\
\hline 115 to 120 & -15 to -20 & Dark grey, massive, hard basalt & Similar to above \\
\hline 120 to 125 & -20 to -25 & Dark grey, massive, hard basalt & Darker than above \\
\hline 125 to 130 & -25 to -30 & Dark grey, massive, hard basalt & Similar to above \\
\hline 130 to 135 & -30 to -35 & Some massive rock as above; some red, hard basalt & \\
\hline 135 to 140 & -35 to -40 & Red, hard, highly vesicular basalt & \\
\hline 140 to 145 & -40 to -45 & Grey, hard, highly vesicular basalt & \\
\hline 145 to 150 & -45 to -50 & Grey, hard, highly vesicular basalt & \\
\hline 150 to 155 & -50 to -55 & Grey, hard, highly vesicular basalt & \\
\hline 155 to 160 & -55 to -60 & Grey, hard, highly vesicular basalt & \\
\hline 160 to 165 & -60 to -65 & Grey, hard, slightly vesicular basalt; some reddish material & \\
\hline 165 to 170 & -65 to -70 & Grey, highly vesicular basalt & Some large, loose chunks \\
\hline 170 to 175 & -70 to -75 & Grey, hard, slightly vesicular basalt & Small, angular chips \\
\hline 175 & -75 & Grey, hard, slightly vesicular basalt & Lighter grey than above \\
\hline
\end{tabular}


Table 5. Driller's log for Thompson Corner exploratory well I (State well number 3-3307-20), Oahu, Hawaii. [Elevation datum is mean sea level]

\begin{tabular}{|c|c|c|c|}
\hline $\begin{array}{c}\text { Depth below } \\
\text { grade } \\
\text { (feet) }\end{array}$ & $\begin{array}{c}\text { Elevation } \\
\text { (feet) }\end{array}$ & & Description \\
\hline 0 to 12 & 99 to 87 & & Red saprolite \\
\hline 12 to 14 & 87 to 85 & & Grey boulder \\
\hline 14 to 18 & 85 to 81 & & Red saprolite \\
\hline 18 to 21 & 81 to 78 & & Grey boulders \\
\hline 21 to 25 & 78 to 74 & & Grey hard rock \\
\hline 25 to 62 & 74 to 37 & & Grey firm rock \\
\hline 62 to 63 & 37 to 36 & & Grey very soft rock \\
\hline 63 to 66 & 36 to 33 & & Grey soft rock \\
\hline 66 to 69.5 & 33 to 29.5 & & Grey firm rock \\
\hline 69.5 to 70 & 29.5 to 29 & & Red soft rock \\
\hline 70 to 73 & 29 to 26 & & Grey firm rock \\
\hline 73 to 74 & 26 to 25 & & Grey soft rock \\
\hline 74 to 76 & 25 to 23 & & Grey, moist, very soft rock \\
\hline 76 to 85 & 23 to 14 & & Grey, moist, firm rock \\
\hline 85 to 89.5 & 14 to 9.5 & & Grey, firm, dry rock \\
\hline 89.5 to 92 & 9.5 to 7 & & Brownish grey, moist, soft, washed cuttings \\
\hline 92 to 101.5 & 7 to -2.5 & & Soft, no return, water measured at $91 \mathrm{ft}$ from pad \\
\hline 101.5 to 103 & -2.5 to -4 & & Soft, circulation returned, lots of water \\
\hline 103 to 125 & -4 to -26 & & Hard, solid rock \\
\hline 125 to 127 & -26 to -28 & .1 & Hard, broken rock \\
\hline 127 to 130 & -28 to -31 & & Red clinkers, soft, broken rock, lots of water \\
\hline 130 to 146.5 & -31 to -47.5 & & Firm rock, highly fractured \\
\hline 146.5 to 161 & -47.5 to -62 & & Grey, broken, soft rock \\
\hline 161 to 164 & -62 to -65 & & Soft \\
\hline 164 to 168 & -65 to -69 & & Weathered, broken \\
\hline 168 to 181 & -69 to -82 & & Hard, broken rock \\
\hline
\end{tabular}


Table 6. Driller's log for the Thompson Corner exploratory well II (State well number 3-3307-20), Oahu, Hawaii [Elevation datum is mean sea Ievel]

\begin{tabular}{|c|c|c|}
\hline $\begin{array}{c}\text { Depth below } \\
\text { grade } \\
\text { (feet) }\end{array}$ & $\begin{array}{c}\text { Elevation } \\
\text { (feet) }\end{array}$ & Description \\
\hline 0 to 12 & 100 to 88 & Red saprolite \\
\hline 12 to 13 & 88 to 87 & Grey rock \\
\hline 13 to 16 & 87 to 84 & Red saprolite \\
\hline 16 to 21 & 84 to 79 & Grey, oxidized clay and rock \\
\hline 21 to 24 & 79 to 76 & Red and grey soft rock \\
\hline 24 to 29 & 76 to 71 & Grey, hard rock \\
\hline 29 to 30 & 71 to 70 & Grey, soft rock \\
\hline 30 to 32 & 70 to 68 & Grey, hard rock \\
\hline 32 to 35 & 68 to 65 & Grey moist fractured rock \\
\hline 35 to 36 & 65 to 64 & Grey, firm rock \\
\hline 36 to 36.5 & 64 to 63.5 & Grey, soft rock \\
\hline 36.5 to 45 & 63.5 to 55 & Grey, very hard rock \\
\hline 45 to 48 & 55 to 52 & Grey, soft moist rock \\
\hline 48 to 52 & 52 to 48 & Grey, hard dry rock \\
\hline 52 to 57 & 48 to 43 & Grey, soft moist cuttings \\
\hline 57 to 58 & 43 to 42 & Dry soft rock \\
\hline 58 to 63 & 42 to 37 & Grey, soft rock \\
\hline 63 to 65 & 37 to 35 & Grey, medium firm rock \\
\hline 65 to 72 & 35 to 28 & Grey, moist soft rock \\
\hline 72 to 78 & 28 to 22 & Red, soft rock \\
\hline 78 to 82 & 22 to 18 & Red, grey soft rock \\
\hline 82 to 84 & 18 to 16 & Grey, medium hard rock \\
\hline 84 to 85 & 16 to 15 & Grey, hard rock \\
\hline 85 to 86 & 15 to 14 & Moist, soft rock \\
\hline 86 to 96 & 14 to 4 & Grey, hard, dry rock \\
\hline 96 to 103 & 4 to -3 & Red, packed clinker \\
\hline 103 to 118 & -3 to -18 & Very hard with few small fractures, water \\
\hline 118 to 126 & -18 to -26 & More fractured rock, more water \\
\hline 126 to 128 & -26 to -28 & Large stained fractured chips, significantly more water \\
\hline 128 to 132 & -28 to -32 & Soft \\
\hline 132 to 133 & -32 to -33 & Void \\
\hline 133 to 134 & -33 to -34 & Red, very weathered rock \\
\hline 134 to 136 & -34 to -36 & Firm \\
\hline 136 to 139 & -36 to -39 & Soft \\
\hline 139 to 147 & -39 to -47 & Firm pahoehoe with brown dirt \\
\hline 147 to 157 & -47 to -57 & Fast, firm, brownish grey pahoehoe \\
\hline 157 to 158 & -57 to -58 & Red rock \\
\hline 158 to 159 & -58 to -59 & Pahoehoe, brownish \\
\hline 159 to 161 & -59 to -61 & Grey, weathered fracture zone \\
\hline 161 to 165 & -61 to -65 & Firm rock \\
\hline 165 to 166 & -65 to -66 & Grey, weathered rock \\
\hline 166 to 167 & -66 to -67 & Firm rock \\
\hline 167 to 170 & -67 to -70 & Very hard rock \\
\hline 170 to 176 & -70 to -76 & Soft, coherent rock \\
\hline 176 to 177 & -76 to -77 & Very hard rock \\
\hline 177 to 180 & -77 to -80 & Firm rock \\
\hline
\end{tabular}


Table 7. Water-level measurements for constant-pumping-rate aquifer test of July 28-30, 1993, Thompson Corner exploratory wells I and II (State well numbers 3-3307-20 and -21)

[The measuring point elevation for well 3-3307-20 is $101.11 \mathrm{ft}$, and the measuring point elevation for well 3-3307-21 is $101.40 \mathrm{ft}$; --, no measurement; datum for water levels is mean sea level]

\begin{tabular}{|c|c|c|c|c|c|c|}
\hline \multirow[b]{2}{*}{ Date } & \multirow[b]{2}{*}{ Time } & \multicolumn{2}{|c|}{ Pumped well 3-3307-20 } & \multicolumn{2}{|c|}{ Observation well 3-3307-21 } & \multirow{2}{*}{$\begin{array}{l}\text { Totallzlng flow } \\
\text { meter reading } \\
\text { (gallons) }\end{array}$} \\
\hline & & $\begin{array}{c}\text { Depth to water, } \\
\text { (feet) }\end{array}$ & $\begin{array}{c}\text { Water level, } \\
\text { (feet) }\end{array}$ & $\begin{array}{c}\text { Depth to water, } \\
\text { (feet) }\end{array}$ & $\begin{array}{c}\text { Water level, } \\
\text { (feet) }\end{array}$ & \\
\hline \multirow[t]{28}{*}{ July 28,1993} & $11: 53: 00$ & $\begin{array}{l}\text { Electric measuring } \\
\text { tape failed }\end{array}$ & -- & -- & -- & -- \\
\hline & 11:55:00 & -- & -- & 90.19 & 11.21 & -- \\
\hline & 12:00:00 & Start pump & -- & -- & -- & 8,948 \\
\hline & $12: 00: 20$ & -- & - & 90.19 & 11.21 & -- \\
\hline & $12: 00: 40$ & -- & -- & 90.19 & 11.21 & -- \\
\hline & $12: 01: 00$ & -- & - & 90.19 & 11.21 & -- \\
\hline & $12: 01: 20$ & -- & -- & 90.19 & 11.21 & -- \\
\hline & $12: 01: 40$ & -- & -- & 90.19 & 11.21 & -- \\
\hline & 12:02:00 & -- & - & 90.19 & 11.21 & - \\
\hline & $12: 02: 20$ & -- & -- & 90.20 & 11.21 & -- \\
\hline & $12: 02: 40$ & -- & -- & 90.19 & 11.21 & -- \\
\hline & $12: 03: 00$ & -- & - & 90.20 & 11.21 & -- \\
\hline & $12: 03: 20$ & -- & -- & 90.20 & 11.21 &.- \\
\hline & $12: 03: 40$ & -- & -- & 90.20 & 11.20 & -- \\
\hline & $12: 04: 00$ & -- & -- & 90.20 & 11.20 & -- \\
\hline & $12: 04: 20$ & -- & - & 90.20 & 11.21 & - \\
\hline & $12: 04: 40$ & -- & - & 90.20 & 11.20 & -- \\
\hline & $12: 05: 00$ & -- & - & 90.20 & 11.21 & - \\
\hline & $12: 05: 20$ & -- & -- & 90.20 & 11.21 & -- \\
\hline & $12: 05: 40$ & -- & -. & 90.20 & 11.21 & -- \\
\hline & $12: 06: 20$ & - & - & 90.20 & 11.20 & - \\
\hline & $12: 06: 40$ & -- & - & 90.20 & 11.20 & -- \\
\hline & $12: 07: 00$ & -- & -- & 90.20 & 11.20 & -- \\
\hline & 12:08:00 & -- & -- & 90.20 & 11.20 & -. \\
\hline & $12: 09: 00$ & -- & -- & 90.20 & 11.20 & -- \\
\hline & $12: 10: 00$ & -- & -- & 90.20 & 11.20 & - \\
\hline & $12: 11: 00$ & -- & - & 90.20 & 11.20 & -- \\
\hline & $12: 12: 00$ & -- & -- & 90.20 & 11.20 & -- \\
\hline \multirow[t]{28}{*}{ July 28, 1993} & $12: 13: 00$ & -- & -- & 90.20 & 11.20 & -- \\
\hline & $12: 14: 00$ & -- & -- & 90.20 & 11.20 & -- \\
\hline & $12: 15: 00$ & - & -- & 90.20 & 11.20 & -- \\
\hline & $12: 20: 00$ & -- & -- & 90.20 & 11.20 & -- \\
\hline & $12: 25: 00$ & - & -- & 90.20 & 11.20 & -- \\
\hline & $12: 50: 00$ & -- & -- & 90.19 & 11.21 & -- \\
\hline & $12: 55: 00$ & - & - & 90.19 & 11.21 & -- \\
\hline & 13:08:34 & -- & -- & -- & -- & 50,000 \\
\hline & $13: 10: 35$ & - & - & -- & -- & 51,000 \\
\hline & $13: 12: 35$ & -- & -- & -- & -- & 52,000 \\
\hline & $13: 14: 31$ & -- & -- & -- & -- & 53,000 \\
\hline & $13: 20: 25$ & - & - & -- & -- & 56,300 \\
\hline & $13: 21: 15$ & -- & -- & 90.19 & 11.22 & -- \\
\hline & $13: 22: 25$ & - & -- & -- & -- & 57,300 \\
\hline & $13: 23: 49$ & - & -- & -- & -- & 58,000 \\
\hline & $13: 29: 48$ & -- & -- & -- & -- & 61,000 \\
\hline & $13: 31: 45$ & - & -- & 90.18 & 11.22 & -- \\
\hline & $13: 37: 20$ & - & - & -- & -- & 65,000 \\
\hline & 13:58:00 & - &.- & 90.17 & 11.23 & -- \\
\hline & $14: 00: 00$ & -- & -- & 90.17 & 11.23 & -- \\
\hline & $14: 20: 00$ & - & -- & 90.17 & 11.23 & - \\
\hline & $14: 24: 55$ & -- & -- & -- & -- & 91,000 \\
\hline & $14: 26: 43$ & - & -- & - & -- & 92,000 \\
\hline & $14: 28: 33$ & - & -- & - & -- & 93,000 \\
\hline & $14: 40: 00$ & -- & -- & 90.17 & 11.24 & -- \\
\hline & $15: 30: 00$ & -- & - & 90.16 & 11.24 & -- \\
\hline & $15: 36: 38$ & -- & -- & -- & -- & 131,700 \\
\hline & $16: 40: 00$ & -- & -- & 90.16 & 11.24 & -- \\
\hline
\end{tabular}


Table 7. Water-level measurements for constant-pumping-rate aquifer test of July 28-30, 1993, Thompson Corner exploratory wells I and II (State well numbers 3-3307-20 and -21)--Continued

[The measuring point elevation for well 3-3307-20 is $101.11 \mathrm{ft}$, and the measuring point elevation for well 3-3307-21 is $101.40 \mathrm{ft}$; --, no measurement; datum for water levels is mean sea level]

\begin{tabular}{|c|c|c|c|c|c|c|}
\hline \multirow[b]{2}{*}{ Date } & \multirow[b]{2}{*}{ Time } & \multicolumn{2}{|c|}{ Pumped well 3-3307-20 } & \multicolumn{2}{|c|}{ Observation well 3-3307-21 } & \multirow{2}{*}{$\begin{array}{l}\text { Totalizing flow } \\
\text { meter reading, } \\
\text { (gallons) }\end{array}$} \\
\hline & & $\begin{array}{l}\text { Depth to water, } \\
\text { (feet) }\end{array}$ & $\begin{array}{c}\text { Water level, } \\
\text { (feet) }\end{array}$ & $\begin{array}{l}\text { Depth to water, } \\
\text { (feet) }\end{array}$ & $\begin{array}{c}\text { Water level, } \\
\text { (feet) }\end{array}$ & \\
\hline \multirow{24}{*}{ July 28,1993} & $16: 42: 16$ & -- & -- & $\overline{--}$ & -- & 171,400 \\
\hline & $16: 43: 55$ & -- & -- & -- & -- & 172,400 \\
\hline & $16: 45: 33$ & -- & -- & -- & -- & 173,400 \\
\hline & $16: 47: 12$ & -- & -- & -- & -- & 174,400 \\
\hline & $17: 30: 00$ & -- & -- & 90.16 & 11.24 & -- \\
\hline & $17: 57: 00$ & 90.83 & 10.28 & - & -- & -- \\
\hline & $17: 58: 33$ & -- & -- & -- & -- & 215,500 \\
\hline & 18:00:23 & -- & -- & -- & -- & 216,500 \\
\hline & $18: 30: 00$ & 90.81 & 10.30 & -- & -- & -- \\
\hline & $18: 35: 00$ & -- & -- & 90.16 & 11.24 & -- \\
\hline & 19:58:00 & -- & -- & 90.18 & 11.22 & -- \\
\hline & 20:00:00 & 90.82 & 10.29 & -- & -- & -- \\
\hline & $21: 20: 00$ & 90.84 & 10.27 & -- & -- & -- \\
\hline & $21: 35: 00$ & - & -- & 90.20 & 11.20 & -- \\
\hline & $21: 42: 30$ & -- & - & -- & -- & 350,000 \\
\hline & $21: 45: 48$ & -- & - & -- & -- & 352,000 \\
\hline & $21: 47: 25$ & -- & -- & -- & - & 353,000 \\
\hline & $21: 49: 03$ & -- & -- & -- & -- & 354,000 \\
\hline & $22: 20: 00$ & -- & -. & 90.20 & 11.20 & -- \\
\hline & $22: 30: 00$ & 90.85 & 10.26 & -- & -- & -- \\
\hline & $23: 14: 02$ &.- & -- & -- & -- & 406,000 \\
\hline & $23: 15: 39$ & -- & -- & -- & -- & 407,000 \\
\hline & $23: 27: 05$ & -- & -- & -- & -- & 414,000 \\
\hline & $23: 30: 00$ & 90.85 & 10.26 & 90.21 & 11.19 & -- \\
\hline \multirow[t]{8}{*}{ July 29, 1993} & $00: 29: 00$ & -. & -- & 90.21 & 11.19 & -- \\
\hline & $00: 34: 00$ & 90.86 & 10.25 & -- & -- & -- \\
\hline & $00: 35: 44$ & -- & -- & -- & -- & 456,000 \\
\hline & $00: 40: 40$ & -- & -- & -- & -- & 459,000 \\
\hline & $00: 43: 55$ & -- & -- & -- & -- & 461,000 \\
\hline & $00: 45: 33$ & -- & -- & -- & -- & 462,000 \\
\hline & $00: 57: 00$ & 90.86 & 10.25 & -- & -- & - \\
\hline & 01:00:00 & -- & -- & 90.21 & 11.19 & - \\
\hline \multirow{24}{*}{ July 29,1993} & $01: 56: 00$ & -. & -- & 90.22 & 11.18 & -- \\
\hline & 02:03:00 & 90.86 & 10.25 & -- & -. & -- \\
\hline & $02: 08: 52$ & - & -- & -- & -- & 513,000 \\
\hline & $02: 10: 32$ & -- & -- & -- & -- & 514,000 \\
\hline & $02: 12: 08$ & -- & -- & -- & - & 515,000 \\
\hline & $02: 13: 46$ & -- & -- & -- & -- & 516,000 \\
\hline & 02:57:00 & 90.87 & 10.24 & -- & -- & -- \\
\hline & 03:02:00 & -- & - & 90.23 & 11.17 & - \\
\hline & 03:02:49 & -- & -- & -- & -- & 546,000 \\
\hline & $03: 04: 27$ & -- & -- & -- & -- & 547,000 \\
\hline & 03:06:05 & -- & -- & -- & $\cdots$ & 548,000 \\
\hline & 03:07:43 & -- & -- & -- & -. & 549,000 \\
\hline & 04:06:00 & -- & -- & 90.26 & 11.15 & -- \\
\hline & 04:09:00 & 90.90 & 10.21 & -- & -- & -- \\
\hline & $04: I 1: 26$ & -- & $\ldots$ & -- & -- & 588,000 \\
\hline & 04:13:04 & -- & -- & -- & -- & 589,000 \\
\hline & $04: 14: 43$ & -- & -- & -- & -- & 590,000 \\
\hline & $04: 16: 21$ & -- & -- & -- & -- & 591,000 \\
\hline & $05: 25: 00$ & 90.91 & 10.20 & -- & -- & -- \\
\hline & 05:30:00 & -- & -- & 90.28 & 11.13 & -- \\
\hline & $05: 31: 53$ & -- & -- & -- & -- & 632,000 \\
\hline & $05: 33: 57$ & -- & -- & -- & - & 633,000 \\
\hline & $05: 35: 50$ & -- & -- & -- & -- & 634,000 \\
\hline & $05: 37: 43$ & -- & - & -- & -- & 635,000 \\
\hline
\end{tabular}


Table 7. Water-level measurements for constant-pumping-rate aquifer test of July $28-30,1993$, Thompson Corner exploratory wells I and II (State well numbers 3-3307-20 and -21)--Continued

[The measuring point elevation for well 3-3307-20 is $101.11 \mathrm{ft}$, and the measuring point elevation for well 3-3307-21 is $101.40 \mathrm{ft}$; --, no measurement; datum for water levels is mean sea level]

\begin{tabular}{|c|c|c|c|c|c|c|}
\hline \multirow[b]{2}{*}{ Date } & \multirow[b]{2}{*}{ Time } & \multicolumn{2}{|c|}{ Pumped well 3-3307-20 } & \multicolumn{2}{|c|}{ Observation well 3-3307-21 } & \multirow{2}{*}{$\begin{array}{l}\text { Totallzing flow } \\
\text { meter reading, } \\
\text { (gallons) }\end{array}$} \\
\hline & & $\begin{array}{l}\text { Depth to water, } \\
\text { (feet) }\end{array}$ & $\begin{array}{c}\text { Water level, } \\
\text { (feet) }\end{array}$ & $\begin{array}{l}\text { Depth to water, } \\
\text { (feet) }\end{array}$ & $\begin{array}{c}\text { Water level, } \\
\text { (feet) }\end{array}$ & \\
\hline & $06: 20: 00$ & -- & $\overline{--}$ & 90.29 & $\overline{11.12}$ & -- \\
\hline & $06: 22: 00$ & 90.93 & 10.18 & -- & -. & -- \\
\hline & 07:48:00 & 90.94 & 10.17 & -- & -- & -- \\
\hline & $07: 52: 00$ & -- & -- & 90.31 & 11.09 & -- \\
\hline & $07: 55: 58$ & -- & -- & - & -- & 714,000 \\
\hline & $07: 57: 37$ & -- & -- & -- & -- & 715,000 \\
\hline \multirow[t]{30}{*}{ July 29,1993} & 07:59:15 & -- & -- & -- & -- & 716,000 \\
\hline & $08: 00: 53$ & -- & -- & -- & -- & 717,000 \\
\hline & 08:33:00 & -- & -- & 90.31 & 11.10 & -- \\
\hline & $08: 37: 00$ & 90.94 & 10.17 & -- & -- & - \\
\hline & $08: 57: 00$ & -- & -- & 90.29 & 11.11 & -- \\
\hline & 09:54:00 & 90.94 & 10.17 & -- & -. & - \\
\hline & $09: 58: 45$ & -- & -- & -- & -- & 789,000 \\
\hline & $10: 00: 24$ & -- & -- & -- & -- & 790,000 \\
\hline & $10: 02: 01$ & -- & -. & - & -- & 791,000 \\
\hline & $10: 03: 39$ & -- & -- & -- & -- & 792,000 \\
\hline & $10: 56: 00$ & -- & -- & 90.28 & 11.12 & -- \\
\hline & 11:00:00 & 90.92 & 10.19 & -- & -- & -- \\
\hline & 11:02:28 & $\ldots$ & - & -- & -- & 828,000 \\
\hline & 11:04:06 & -- & -- & -- & -- & 829,000 \\
\hline & $11: 05: 45$ & -- & $\cdots$ & - & -- & 830,000 \\
\hline & $11: 07: 25$ & -- & -- & -- & -- & 831,000 \\
\hline & 11:55:00 & 90.90 & 10.21 & -- & -- & -- \\
\hline & $12: 05: 00$ & -- & -- & 90.26 & 11.15 & -- \\
\hline & $13: 20: 00$ & -- & -- & 90.22 & 11.18 & -- \\
\hline & $13: 40: 00$ & 90.84 & 10.27 & -- & -- & -- \\
\hline & $14: 47: 00$ & 90.87 & 10.24 & -- & -- & -- \\
\hline & $14: 50: 00$ & - &.- & 90.21 & 11.19 & -- \\
\hline & $15: 32: 00$ & -- & -- & 90.20 & 11.20 & -- \\
\hline & $15: 35: 00$ & 90.85 & 10.26 & -- & -- & -- \\
\hline & 18:05:00 & 90.84 & 10.27 & -- & -- & -- \\
\hline & 18:07:00 & -- & -- & 90.19 & 11.21 & -- \\
\hline & $19: 30: 00$ & -- & -- & 90.20 & 11.20 & -- \\
\hline & $19: 32: 00$ & 90.82 & 10.29 & -- & -- & - \\
\hline & $20: 35: 00$ & 90.87 & 10.24 & -- & -- & -- \\
\hline & $20: 43: 00$ & - & -- & 90.22 & 11.18 & -- \\
\hline \multirow[t]{6}{*}{ July 29,1993} & $22: 19: 00$ & 90.88 & 10.23 & 90.23 & 11.18 & -- \\
\hline & $23: 09: 00$ & 90.88 & 10.23 & -- & -- & -- \\
\hline & $23: 13: 00$ & -- & - & 90.26 & 11.15 & -- \\
\hline & $23: 14: 49$ & - & -- & -- & -- & $1,276,000$ \\
\hline & $23: 16: 27$ & -- & -- & -- & -- & $1,277,000$ \\
\hline & $23: 18: 04$ & - & -- & -- & -- & $1,278,000$ \\
\hline \multirow[t]{14}{*}{ July 30,1993} & 00:00:00 & -- & -- & 90.23 & 11.17 & -- \\
\hline & $00: 05: 00$ & 90.88 & 10.23 & -- & -- & - \\
\hline & $00: 07: 03$ & -- & -- & -- & -- & $1,308,000$ \\
\hline & $00: 08: 41$ & - & -- & -- & -- & $1,309,000$ \\
\hline & $00: 10: 19$ & -- & -- & -- & -- & $1,310,000$ \\
\hline & 01:00:00 & 90.88 & 10.23 & -- & -- & -- \\
\hline & $01: 04: 12$ & -- & -- & -- & -- & $1,343,000$ \\
\hline & $01: 05: 50$ & -- & -- & -- &.- & $1,344,000$ \\
\hline & $01: 07: 27$ & - & -- & -- & - & $1,345,000$ \\
\hline & $01: 10: 00$ & -- & -- & 90.24 & 11.17 & -- \\
\hline & 02:00:00 & -- & -- & 90.24 & 11.17 & -- \\
\hline & $02: 05: 00$ & 90.89 & 10.22 & -- & -- & -- \\
\hline & $02: 06: 15$ & -- & -- & -- & -- & $1,381,000$ \\
\hline & $02: 07: 53$ & -- & -- & -- & -- & $1,382,000$ \\
\hline
\end{tabular}


Table 7. Water-level measurements for constant-pumping-rate aquifer test of July 28-30, 1993, Thompson Corner exploratory wells I and II (State well numbers 3-3307-20 and -21)--Continued

[The measuring point elevation for well 3-3307-20 is $101.11 \mathrm{ft}$, and the measuring point elevation for well 3-3307-21 is $101.40 \mathrm{ft}$; --, no measurement; datum for water levels is mean sea level]

\begin{tabular}{|c|c|c|c|c|c|c|}
\hline \multirow[b]{2}{*}{ Date } & \multirow[b]{2}{*}{ Time } & \multicolumn{2}{|c|}{ Pumped well 3-3307-20 } & \multicolumn{2}{|c|}{ Observation well 3-3307-21 } & \multirow{2}{*}{$\begin{array}{l}\text { Totalizing flow } \\
\text { meter reading, } \\
\text { (gallons) }\end{array}$} \\
\hline & & $\begin{array}{l}\text { Depth to water, } \\
\text { (feet) }\end{array}$ & $\begin{array}{c}\text { Water level, } \\
\text { (feet) }\end{array}$ & $\begin{array}{l}\text { Depth to water, } \\
\text { (feet) }\end{array}$ & $\begin{array}{c}\text { Water level, } \\
\text { (feet) }\end{array}$ & \\
\hline & $02: 09: 30$ & -- & $\overline{-}$ & $\overline{-}$ & -- & $1,383,000$ \\
\hline & 03:00:00 & 90.89 & 10.22 & -- & -- & -- \\
\hline & 03:05:05 & -- & -- & -- & -- & $1,417,000$ \\
\hline & 03:06:44 & -- & - & -- & -- & $1,418,000$ \\
\hline & 03:08:22 & -- & -- & -- & -- & $1,419,000$ \\
\hline & 03:11:00 & -- & -- & 90.26 & 11.14 & -- \\
\hline & 04:02:00 & -- & -- & 90.27 & 11.13 & -- \\
\hline & 04:06:00 & 90.92 & 10.19 & - & - & -- \\
\hline & 04:07:13 & -- & -. & -- & -. & $1,455,000$ \\
\hline & 04:08:52 & -- & -- & -- & -- & $1,456,000$ \\
\hline \multirow[t]{30}{*}{ July 30,1993} & $04: 10: 30$ & -- & - & -- & -- & $1,457,000$ \\
\hline & $04: 55: 00$ & 90.93 & 10.18 & -- & -- & - \\
\hline & $04: 57: 47$ & - & -- & -- & -- & $1,486,000$ \\
\hline & $04: 59: 25$ & -- & -- & -- & -- & $1,487,000$ \\
\hline & $05: 01: 03$ & -- & -- & -- & -- & $1,488,000$ \\
\hline & 05:05:00 & -- & - & 90.28 & 11.12 & -- \\
\hline & $05: 50: 00$ & -- & - & 90.29 & 11.11 & -- \\
\hline & $05: 55: 00$ & 90.95 & 10.16 & - & -- & -. \\
\hline & $05: 56: 30$ & -- & - & -- & -- & $1,522,000$ \\
\hline & $05: 58: 08$ & -- & - & - & -- & $1,523,000$ \\
\hline & $05: 59: 46$ & -- & -- & -- & -- & $1,524,000$ \\
\hline & $06: 59: 00$ & 90.96 & 10.15 & -- & -- & - \\
\hline & $07: 01: 45$ & -- & -- & -. & -. & $1,562,000$ \\
\hline & $07: 03: 24$ & -. & -- & - & .. & $1,563,000$ \\
\hline & $07: 05: 02$ & -- & -- & -- & -- & $1,564,000$ \\
\hline & $07: 14: 00$ & -- & -- & 90.32 & 11.08 & -- \\
\hline & $07: 51: 00$ & -- & - & 90.32 & 11.09 & -- \\
\hline & $07: 55: 00$ & 90.96 & 10.15 & - & -- & -- \\
\hline & $07: 57: 17$ & - & -. & - & -. & $1,596,000$ \\
\hline & $07: 58: 55$ & -- & -- & -- & -. & $1,597,000$ \\
\hline & 08:00:33 & -- & .. & - & -- & $1,598,000$ \\
\hline & $09: 04: 00$ & 90.96 & 10.15 & -- & -. & -- \\
\hline & $09: 06: 00$ & -- & -- & 90.32 & 11.09 & -- \\
\hline & 09:09:11 & -- & -- & -- & -- & $1,640,000$ \\
\hline & $09: 10: 49$ & -- & -- & -- & -- & $1,641,000$ \\
\hline & $09: 12: 27$ & -- & - & -- & -. & $1,642,000$ \\
\hline & $09: 56: 00$ & -- & -- & 90.32 & 11.09 & -- \\
\hline & $10: 00: 00$ & 90.96 & 10.15 & -- & -- & -- \\
\hline & 10:03:06 & -- & -- & -- & -- & $1,673,000$ \\
\hline & $10: 04: 45$ & -- & -- & -- & -- & $1,674,000$ \\
\hline \multirow[t]{16}{*}{ July 30, 1993} & $10: 06: 23$ & -- &.- & -- & -- & $1,675,000$ \\
\hline & 11:02:00 & 90.93 & 10.18 & -- & -- & -- \\
\hline & 11:10:00 & -- & - & 90.31 & 11.09 & -- \\
\hline & $11: 30: 00$ & -- & -- & 90.30 & 11.10 & -- \\
\hline & 11:37:00 & -- & -- & 90.30 & 11.10 & -- \\
\hline & 11:40:00 & 90.90 & 10.21 & -- & -. & -- \\
\hline & 12:00:00 & stop pump & -- & -- & -- & $1,744,543$ \\
\hline & $12: 00: 25$ & -- & -- & 90.28 & 11.12 & -- \\
\hline & $12: 00: 50$ & -- & -- & 90.29 & 11.11 & -- \\
\hline & $12: 01: 30$ & -- & - & 90.28 & 11.12 & -- \\
\hline & 12:02:00 & - & -- & 90.29 & 11.11 & -- \\
\hline & $12: 02: 45$ & -- & -- & 90.29 & 11.11 & -- \\
\hline & $12: 03: 30$ & - & -- & 90.29 & 11.12 & -- \\
\hline & $12: 04: 00$ & -- & - & 90.29 & 11.11 & -- \\
\hline & $12: 05: 30$ & - & -- & 90.29 & 11.11 & -- \\
\hline & 12:06:00 & - & -- & 90.29 & 11.12 & - \\
\hline
\end{tabular}


Table 7. Water-level measurements for constant-pumping-rate aquifer test of July 28-30, 1993, Thompson Corner exploratory wells I and II (State well numbers 3-3307-20 and -21)--Continued

[The measuring point elevation for well 3-3307-20 is $101.11 \mathrm{ft}$, and the measuring point elevation for well 3-3307-21 is $101.40 \mathrm{ft}$; --, no measurement; datum for water levels is mean sea level]

\begin{tabular}{|c|c|c|c|c|c|c|}
\hline \multirow[b]{2}{*}{ Date } & \multirow[b]{2}{*}{ Time } & \multicolumn{2}{|c|}{ Pumped well 3-3307-20 } & \multicolumn{2}{|c|}{ Observation well 3-3307-21 } & \multirow{2}{*}{$\begin{array}{l}\text { Totallzing flow } \\
\text { meter reading } \\
\text { (gallons) }\end{array}$} \\
\hline & & $\begin{array}{c}\text { Depth to water, } \\
\text { (feet) }\end{array}$ & $\begin{array}{l}\text { Water level, } \\
\text { (feet) }\end{array}$ & $\begin{array}{c}\text { Depth to water, } \\
\text { (feet) }\end{array}$ & $\begin{array}{c}\text { Water level, } \\
\text { (feet) }\end{array}$ & \\
\hline & $12: \overline{07}: \overline{00}$ & -- & -- & 90.29 & 11.12 & $\overline{--}$ \\
\hline & $12: 15: 00$ & -- & -- & 90.28 & 11.12 & -- \\
\hline & $12: 30: 00$ & -- & -- & 90.28 & 11.12 & -- \\
\hline & $13: 58: 00$ & - & -- & 90.23 & 11.18 & -- \\
\hline & $14: 00: 00$ & 89.92 & 11.19 & -- & -. & -- \\
\hline
\end{tabular}


Table 8. Water-level measurements for constant-pumping-rate aquifer test of August 5-7, 1993, Thompson Corner exploratory wells I and II (State well numbers 3-3307-20 and 21)

[The measuring point elevation for well 3-3307-20 is $101.11 \mathrm{ft}$, and the measuring point elevation for well 3-3307-21 is $101.40 \mathrm{ft}$; - , no measurement; datum for water levels is mean sea level]

\begin{tabular}{|c|c|c|c|c|c|c|}
\hline \multirow[b]{2}{*}{ Date } & \multirow[b]{2}{*}{ Time } & \multicolumn{2}{|c|}{ Pumped Well 3-3307-20 } & \multicolumn{2}{|c|}{ Observation Well 3-3307-21 } & \multirow[b]{2}{*}{$\begin{array}{l}\text { Totalizing flow } \\
\text { meter reading, } \\
\text { (gallons) }\end{array}$} \\
\hline & & $\begin{array}{c}\text { Depth to water, } \\
\text { (feet) }\end{array}$ & $\begin{array}{c}\text { Water level, } \\
\text { (feet) }\end{array}$ & $\begin{array}{c}\text { Depth to water, } \\
\text { (feet) }\end{array}$ & $\begin{array}{c}\text { Water level, } \\
\text { (feet) }\end{array}$ & \\
\hline \multirow[t]{28}{*}{ August $\overline{5}, 1993$} & $15: 51: 00$ & 89.79 & 11.32 & 90.11 & 11.29 & $\cdots$ \\
\hline & $16: 08: 00$ & 89.79 & 11.32 & -- & -- & -- \\
\hline & $16: 22: 00$ & 89.80 & 11.31 & 90.11 & 11.29 & -- \\
\hline & $16: 26: 00$ & - & - & 90.11 & 11.29 & - \\
\hline & $16: 26: 30$ & -- & -- & 90.11 & 11.29 & -- \\
\hline & $16: 30: 00$ & start pump & & 90.11 & 11.29 & $1,829,330$ \\
\hline & $16: 30: 15$ & - & -- & 90.11 & 11.29 & -- \\
\hline & $16: 30: 30$ & -- & -- & 90.14 & 11.27 & -- \\
\hline & $16: 30: 45$ & - & -- & 90.14 & 11.27 & -- \\
\hline & $16: 31: 00$ & -- & -- & 90.14 & 11.26 & -- \\
\hline & $16: 31: 15$ & -- & -- & 90.14 & 11.26 & - \\
\hline & $16: 31: 30$ & - & -- & 90.14 & 11.26 & -- \\
\hline & $16: 32: 00$ & -- & -- & 90.14 & 11.26 & -- \\
\hline & $16: 32: 30$ & -- & -- & 90.14 & 11.26 & - \\
\hline & $16: 33: 00$ & - & -- & 90.14 & 11.26 & -- \\
\hline & $16: 33: 30$ & -- & -- & 90.14 & 11.26 & -- \\
\hline & $16: 34: 00$ & - & -- & 90.14 & 11.26 & -- \\
\hline & $16: 34: 30$ & - & -- & 90.14 & 11.26 & -- \\
\hline & $16: 35: 00$ & -- & -- & 90.14 & 11.26 & -. \\
\hline & $16: 36: 00$ & - & -- & 90.14 & 11.26 & -- \\
\hline & $16: 37: 00$ & - & -- & 90.14 & 11.26 & -- \\
\hline & $16: 38: 00$ & -- & -- & 90.14 & 11.26 & -- \\
\hline & $16: 39: 00$ & -- & -- & 90.14 & 11.26 & -- \\
\hline & $16: 40: 00$ & - & -- & 90.15 & 11.26 & -- \\
\hline & $16: 42: 36$ & - & -- & -- & -- & $1,837,000$ \\
\hline & $16: 44: 14$ & - & -- & -- & - & $1,838,000$ \\
\hline & $16: 45: 00$ & - & -- & 90.15 & 11.25 & -- \\
\hline & $16: 45: 00$ & -- & -- & 90.15 & 11.25 & -- \\
\hline \multirow[t]{22}{*}{ August 5, 1993} & $16: 50: 00$ & -- & -- & 90.14 & 11.26 & -- \\
\hline & $16: 52: 24$ & -- & -- & -- & -- & $1,843,000$ \\
\hline & $16: 55: 00$ & -- & -- & 90.14 & 11.26 & -- \\
\hline & $16: 57: 17$ & - & -- & -- & -- & $1,846,000$ \\
\hline & 17:00:00 & -- & -- & 90.14 & 11.26 & -- \\
\hline & $17: 00: 00$ & -- & -- & 90.14 & 11.26 & -- \\
\hline & $17: 05: 00$ & 90.75 & 10.36 & -- & -- & - \\
\hline & $17: 10: 22$ & -- & -- & -- & -- & $1,854,000$ \\
\hline & 17:11:00 & 90.75 & 10.36 & - & -- & -- \\
\hline & $17: 23: 00$ & 90.75 & 10.36 & -- & -- & -- \\
\hline & $17: 23: 00$ & 90.75 & 10.36 & -- & -- & -- \\
\hline & $17: 26: 00$ & -- & -- & 90.15 & 11.26 & - \\
\hline & $17: 28: 21$ & - & -- & -- & -- & $1,865,000$ \\
\hline & $17: 30: 00$ & - & - & 90.14 & 11.26 & -- \\
\hline & $17: 30: 00$ & -- & -- & 90.14 & 11.26 & -- \\
\hline & $17: 45: 00$ & -- & -- & 90.14 & 11.26 & -- \\
\hline & $17: 45: 00$ & -- & - & 90.14 & 11.26 & -- \\
\hline & $17: 46: 21$ & -- & -- & -- & -- & $1,876,000$ \\
\hline & $17: 46: 21$ & - & -- & -- & -- & $1,876,000$ \\
\hline & $18: 00: 00$ & -- & -- & 90.15 & 11.26 & -- \\
\hline & 18:00:00 & - & -- & 90.15 & 11.26 & - \\
\hline & $18: 02: 44$ & -- & -- & -- & -- & $1,886,000$ \\
\hline
\end{tabular}


Table 8. Water-level measurements for constant-pumping-rate aquifer test of August 5-7, 1993, Thompson Corner exploratory wells I and II (State well numbers 3-3307-20 and 21)--Continued

[The measuring point elevation for well 3-3307-20 is $101.11 \mathrm{ft}$, and the measuring point elevation for well 3-3307-21 is $101.40 \mathrm{ft}$; --, no measurement; datum for water levels is mean sea level]

\begin{tabular}{|c|c|c|c|c|c|c|}
\hline \multirow[b]{2}{*}{ Date } & \multirow[b]{2}{*}{ Time } & \multicolumn{2}{|c|}{ Pumped Well 3-3307-20 } & \multicolumn{2}{|c|}{ Observation Well 3-3307-21 } & \multirow[b]{2}{*}{$\begin{array}{l}\text { Totallzing flow } \\
\text { meter reading, } \\
\text { (gallons) }\end{array}$} \\
\hline & & $\begin{array}{l}\text { Depth to water, } \\
\text { (feet) }\end{array}$ & $\begin{array}{c}\text { Water level, } \\
\text { (feet) }\end{array}$ & $\begin{array}{c}\text { Depth to water, } \\
\text { (feet) }\end{array}$ & $\begin{array}{c}\text { Water level, } \\
\text { (feet) }\end{array}$ & \\
\hline \multirow{18}{*}{ August 5, 1993} & $18: 07: 00$ & 90.73 & 10.38 & -- & -- & -- \\
\hline & $18: 18: 36$ & - & -- & -- & -- & $1,914,000$ \\
\hline & 18:48:00 & 90.73 & 10.38 & -- & -- & -- \\
\hline & 18:52:00 & -- & -- & 90.15 & 11.26 & - \\
\hline & $20: 00: 00$ & - & -- & 90.16 & 11.25 & -- \\
\hline & $20: 02: 00$ & 90.75 & 10.36 & -- & - & -- \\
\hline & $20: 05: 36$ & -- & -- & -- & -- & $1,961,000$ \\
\hline & $21: 06: 00$ & 90.76 & 10.35 & -- & -- & -- \\
\hline & $21: 07: 55$ & -- & -. & -- & -- & $1,99,9000$ \\
\hline & $21: 09: 32$ & -- & -- & -- & -- & $2,000,000$ \\
\hline & $21: 12: 00$ & -- &.- & 90.17 & 11.24 & -- \\
\hline & $21: 58: 00$ & -- & -- & 90.17 & 11.24 & -- \\
\hline & $22: 02: 00$ & 90.77 & 10.34 & -- & -- & -- \\
\hline & $22: 03: 37$ & -- & -- & -- & -- & $2,033,000$ \\
\hline & $23: 04: 00$ & 90.79 & 10.32 & -- & - & -- \\
\hline & $23: 05: 54$ & -- & -- & -- & -- & $2,071,000$ \\
\hline & $23: 10: 00$ & -- & -- & 90.19 & 11.21 & -- \\
\hline & $23: 57: 00$ & -- & -- & 90.19 & 11.21 & -- \\
\hline \multirow[t]{20}{*}{ August 6,1993} & 00:00:00 & 90.80 & 10.31 & -- & -- & -- \\
\hline & $00: 01: 36$ & -- & -- & -. & -- & $2,105,000$ \\
\hline & $00: 57: 00$ & 90.80 & 10.31 & -- & -- & -- \\
\hline & $00: 58: 56$ & -- & -- & - & -- & $2,140,000$ \\
\hline & 01:03:00 & -- & -- & 90.19 & 11.21 & -- \\
\hline & $01: 58: 00$ & -- & -- & 90.20 & 11.21 & - \\
\hline & 02:02:00 & 90.78 & 10.33 & -- & -- & -- \\
\hline & $02: 02: 46$ & - & -- & $-\cdot$ & -- & $2,179,000$ \\
\hline & 02:59:00 & 90.80 & 10.31 & -- & -- & -. \\
\hline & 03:00:00 & - & -- & $\cdots$ & -- & $2,214,000$ \\
\hline & 03:02:00 & - & -- & 90.19 & 11.21 & -- \\
\hline & $04: 16: 00$ & -- & -- & 90.19 & 11.21 & -- \\
\hline & 04:19:00 & 90.78 & 10.33 & -- & -- & -- \\
\hline & $04: 20: 10$ & -- & -- & -- & -- & $2,263,000$ \\
\hline & 06:00:00 & 90.79 & 10.32 & -- & -- & \\
\hline & $06: 01: 30$ & -- & -- & -- & -- & $2,325,000$ \\
\hline & 06:04:00 & - & - & 90.18 & 11.22 & -- \\
\hline & $06: 58: 00$ & - & - & 90.18 & 11.22 & - \\
\hline & $07: 01: 00$ & 90.76 & 10.35 & -- & -- & -- \\
\hline & 07:02:01 & -- & -- & -- & -- & $2,362,000$ \\
\hline \multirow[t]{12}{*}{ August 6, 1993} & 08:03:00 & 90.79 & 10.32 & -- & -- & -- \\
\hline & 08:04:00 & - & -- & -- & -- & $2,400,000$ \\
\hline & 08:07:00 & - & -- & 90.19 & 11.21 & -- \\
\hline & 09:00:00 & - & -- & 90.20 & 11.20 & -- \\
\hline & $09: 02: 30$ & 90.82 & 10.29 & -- & -- & -- \\
\hline & 09:03:00 & -. & - & -- & -- & $2,436,000$ \\
\hline & 10:00:00 & 90.82 & 10.29 & -- & -- & - \\
\hline & 10:02:02 & -- & -- & -- & -- & $2,472,000$ \\
\hline & 10:04:00 & - & -- & 90.21 & 11.19 & -- \\
\hline & $11: 00: 00$ & - & - & 90.22 & 11.19 & -- \\
\hline & 11:03:00 & 90.83 & 10.28 & -- & -- & - \\
\hline & $11: 04: 13$ & -- & -- & -- & - & $2,510,000$ \\
\hline
\end{tabular}


Table 8. Water-level measurements for constant-pumping-rate aquifer test of August 5-7, 1993, Thompson Corner exploratory wells I and II (State well numbers 3-3307-20 and 21)--Continued

[The measuring point elevation for well 3-3307-20 is $101.11 \mathrm{ft}$, and the measuring point elevation for well 3-3307-21 is $101.40 \mathrm{ft}$; --, no measurement; datum for water levels is mean sea level]

\begin{tabular}{|c|c|c|c|c|c|c|}
\hline \multirow[b]{2}{*}{ Date } & \multirow[b]{2}{*}{ Time } & \multicolumn{2}{|c|}{ Pumped Well 3-3307-20 } & \multicolumn{2}{|c|}{ Observation Well 3-3307-21 } & \multirow[b]{2}{*}{$\begin{array}{l}\text { Totalizlng flow } \\
\text { meter reading, } \\
\text { (gallons) }\end{array}$} \\
\hline & & $\begin{array}{c}\text { Depth to water, } \\
\text { (feet) }\end{array}$ & $\begin{array}{c}\text { Water level, } \\
\text { (feet) }\end{array}$ & $\begin{array}{l}\text { Depth to water, } \\
\text { (feet) }\end{array}$ & $\begin{array}{c}\text { Water level, } \\
\text { (feet) }\end{array}$ & \\
\hline & $12: 00: 00$ & 90.83 & 10.28 & -- & - & -- \\
\hline & $12: 03: 00$ & -- & -- & 90.22 & 11.19 & - \\
\hline & $12: 04: 30$ & - & -- & - & -- & $2,547,000$ \\
\hline & 12:58:00 & -- & - & 90.21 & 11.19 & -- \\
\hline & 13:03:00 & 90.82 & 10.29 & -- & -- & - \\
\hline & $13: 03: 48$ & - & -- & -- & -- & $2,583,000$ \\
\hline & $13: 58: 00$ & 90.81 & 10.30 & -- & -- & -- \\
\hline & $13: 59: 29$ & -- & -- & -- & -- & $2,617,000$ \\
\hline & 14:02:00 & - & -- & 90.21 & 11.19 & -- \\
\hline & 14:58:00 & -- & -- & 90.20 & 11.20 & -- \\
\hline & $15: 02: 00$ & 90.80 & 10.31 & -- & -- & -- \\
\hline & $15: 03: 24$ & -- & -- & -- & -- & $2,656,000$ \\
\hline & $15: 59: 00$ & 90.79 & 10.32 & -- & -- & - \\
\hline & 16:00:45 & -- & -- & - & -. & $2,691,000$ \\
\hline & $16: 04: 00$ & -- & - & 90.18 & 11.22 & - \\
\hline & $16: 57: 00$ & - & -- & 90.18 & 11.23 & -- \\
\hline & $17: 00: 00$ & 90.78 & 10.33 & -- & -- & - \\
\hline & $17: 01: 21$ & -- & -- & - & -- & $2,728,000$ \\
\hline \multirow[t]{18}{*}{ August 6, 1993} & 18:01:00 & 90.78 & 10.33 & -- & -- & -- \\
\hline & $18: 01: 54$ & -- & -- & -- & -- & $2,765,000$ \\
\hline & 18:06:00 & -- & -- & 90.17 & 11.24 & -- \\
\hline & 19:00:00 & -- & -- & 90.17 & 11.24 & -- \\
\hline & 19:05:00 & 90.77 & 10.34 & -- & -- & - \\
\hline & $19: 05: 44$ & -- & -- & -- & -- & $2,804,000$ \\
\hline & 19:56:00 & 90.78 & 10.33 & -- & -- & -- \\
\hline & 19:58:06 & -- & -- & -- & -- & $2,836,000$ \\
\hline & 20:01:00 & -- & -- & 90.17 & 11.24 & -- \\
\hline & $20: 51: 00$ & - & -- & 90.18 & 11.23 & - \\
\hline & $20: 55: 00$ & 90.78 & 10.33 & -- & -- & - \\
\hline & $20: 55: 24$ & -- & -- & - & -- & $2,871,000$ \\
\hline & $21: 58: 00$ & 90.78 & 10.33 & - & - & -- \\
\hline & $21: 59: 12$ & -- & -- & -- & - & $2,910,000$ \\
\hline & $22: 01: 00$ & - & -- & 90.18 & 11.22 & - \\
\hline & $22: 56: 00$ & -- & -- & 90.20 & 11.21 & -- \\
\hline & 23:00:00 & 90.81 & 10.30 & -- & -- & - \\
\hline & $23: 01: 25$ & -- & -- & -- & -- & $2,948,000$ \\
\hline \multirow[t]{12}{*}{ August 7, 1993} & 00:03:00 & 90.81 & 10.30 & - & -- & - \\
\hline & $00: 05: 16$ & -- & -- & -- & -- & $2,987,000$ \\
\hline & 00:08:00 & -- & -- & 90.20 & 11.20 & - \\
\hline & $00: 59: 00$ & - & -- & 90.21 & 11.19 & -- \\
\hline & $01: 05: 00$ & 90.82 & 10.29 & -- & -- & -- \\
\hline & $01: 05: 49$ & -- & -- & -- & -- & $3,024,000$ \\
\hline & $02: 02: 00$ & 90.82 & 10.29 & -- & -- & -- \\
\hline & 02:04:44 & -- & -- & -- & -- & $3,060,000$ \\
\hline & 02:08:00 & -- & - & 90.21 & 11.19 & - \\
\hline & 03:02:00 & -- & -- & 90.21 & 11.19 & -- \\
\hline & 03:06:00 & 90.82 & 10.29 & -- & - & - \\
\hline & 03:06:57 & -- & -- & -- & -- & $3,098,000$ \\
\hline \multirow[t]{2}{*}{ August 7, 1993} & 04:05:00 & 90.82 & 10.29 & -- & -- & -- \\
\hline & $04: 07: 31$ & -- & -- & - & -- & $3,135,000$ \\
\hline
\end{tabular}


Table 8. Water-level measurements for constant-pumping-rate aquifer test of August 5-7, 1993, Thompson Corner exploratory wells I and II (State well numbers 3-3307-20 and 21)--Continued

[The measuring point elevation for well 3-3307-20 is $101.11 \mathrm{ft}$, and the measuring point elevation for well 3-3307-21 is $101.40 \mathrm{ft}$; --, no measurement; datum for water levels is mean sea level]

\begin{tabular}{|c|c|c|c|c|c|c|}
\hline \multirow[b]{2}{*}{ Date } & \multirow[b]{2}{*}{ Time } & \multicolumn{2}{|c|}{ Pumped Well 3-3307-20 } & \multicolumn{2}{|c|}{ Observation Well 3-3307-21 } & \multirow[b]{2}{*}{$\begin{array}{l}\text { Totallzing flow } \\
\text { meter reading, } \\
\text { (gallons) }\end{array}$} \\
\hline & & $\begin{array}{c}\text { Depth to water, } \\
\text { (feet) }\end{array}$ & $\begin{array}{c}\text { Water level, } \\
\text { (feet) }\end{array}$ & $\begin{array}{c}\text { Depth to water, } \\
\text { (feet) }\end{array}$ & $\begin{array}{c}\text { Water level, } \\
\text { (feet) }\end{array}$ & \\
\hline & $04: 11: 00$ & - & -- & 90.21 & 11.19 & -- \\
\hline & 05:06:00 & - & -- & 90.21 & 11.19 & -- \\
\hline & $05: 10: 00$ & 90.82 & 10.29 & -- & -- & - \\
\hline & $05: 11: 21$ & -- & -- & -- & - & $3,174,000$ \\
\hline & $06: 02: 00$ & 90.81 & 10.30 & -- & -- & -- \\
\hline & $06: 03: 44$ & -- & - & -- & -- & $3,206,000$ \\
\hline & $06: 06: 00$ & - & -- & 90.21 & 11.20 & -- \\
\hline & $06: 55: 00$ & - & -- & 90.20 & 11.20 & -- \\
\hline & $06: 58: 00$ & 90.81 & 10.30 & -- & -- & -- \\
\hline & $06: 59: 22$ & -- & -- & -- & -- & $3,240,000$ \\
\hline & $07: 56: 00$ & 90.81 & 10.30 & -- & -- & -- \\
\hline & $07: 56: 39$ & -. & -- & -- & -- & $3,275,000$ \\
\hline & 07:59:00 & -- & -- & 90.20 & 11.20 & -- \\
\hline & $08: 55: 00$ & -- & -- & 90.20 & 11.20 & -- \\
\hline & $08: 58: 00$ & 90.81 & 10.30 & -- & -- & -- \\
\hline & $08: 58: 55$ & -- & -- & -- & -- & $3,313,000$ \\
\hline & 10:02:00 & 90.81 & 10.30 & -- & -- & -- \\
\hline & $10: 02: 49$ & -- & -- & -- & -- & $3,352,000$ \\
\hline & $10: 05: 00$ & -- & -- & 90.20 & 11.20 & -- \\
\hline & $10: 58: 00$ & - & -- & 90.20 & 11.20 & - \\
\hline & 11:01:00 & 90.80 & 10.31 & -- & -- & -- \\
\hline & $11: 01: 48$ & -- & - & -- & -- & $3,388,000$ \\
\hline & 12:06:00 & 90.80 & 10.31 & -- & -- & -- \\
\hline & $12: 07: 24$ & -- & -- & -- & -- & $3,428,000$ \\
\hline & 12:09:00 & -- & -- & 90.20 & 11.20 & -- \\
\hline & 13:00:00 & -- & -- & 90.20 & 11.20 & -- \\
\hline & 13:03:00 & 90.80 & 10.31 & -- & -- & -- \\
\hline & 13:04:49 & - & -- & -- & -- & $3,463,000$ \\
\hline \multirow[t]{20}{*}{ August 7,1993} & 14:13:00 & 90.80 & 10.31 & -- & -- & - \\
\hline & $14: 15: 19$ & - & -- & -- & -- & $3,506,000$ \\
\hline & $14: 18: 00$ & -- & -- & 90.19 & 11.22 & -- \\
\hline & $15: 01: 00$ & - & -- & 90.18 & 11.23 & - \\
\hline & 15:04:00 & 90.77 & 10.34 & -- & -- & - \\
\hline & 15:06:09 & -- & - & -- & - & $3,537,000$ \\
\hline & $15: 53: 00$ & 90.77 & 10.34 & -- & -- & -- \\
\hline & $15: 55: 20$ & -- & - & -- & -- & $3,567,000$ \\
\hline & $15: 58: 00$ & -- & -- & 90.16 & 11.24 & -- \\
\hline & $16: 22: 00$ & -- & -- & 90.16 & 11.25 & -- \\
\hline & $16: 23: 12$ & -- & -- & -- & -- & $3,584,000$ \\
\hline & $16: 26: 00$ & -- & -- & 90.16 & 11.25 & \\
\hline & $16: 30: 00$ & stop pump & -. & 90.15 & 11.25 & $3,588,169$ \\
\hline & $16: 35: 00$ & - & -- & 90.12 & 11.28 & -- \\
\hline & $16: 41: 00$ & - & -- & 90.12 & 11.29 & -- \\
\hline & $16: 46: 00$ & - & - & 90.12 & 11.28 & - \\
\hline & $16: 49: 00$ & 89.79 & 11.32 & -- & -- & -- \\
\hline & $16: 55: 00$ & 89.79 & 11.32 & -- & -- & -- \\
\hline & 16:58:00 & -- & - & 90.11 & 11.29 & -- \\
\hline & $17: 11: 00$ & -- & - & 90.11 & 11.29 & -- \\
\hline
\end{tabular}


Table 9. Water-level measurements for step-drawdown test using pumped well Thompson Corner exploratory well I (State well number 3-3307-20), August 4, 1993

[Waialua Sugar Co. Pump 2 may have tumed on during last step. The measuring point elevation for well 3-3307-20 is $101.11 \mathrm{ft}$; --, no measurement; datum for water levels is mean sea level]

\begin{tabular}{|c|c|c|c|}
\hline Time & $\begin{array}{l}\text { Depth to Water } \\
\text { (feet) }\end{array}$ & $\begin{array}{l}\text { Elevation of water surface } \\
\text { (feet) }\end{array}$ & $\begin{array}{l}\text { Totallizing flow } \\
\text { meter reading } \\
\text { (gallons) }\end{array}$ \\
\hline $15: 49$ & 89.69 & 11.419 & - \\
\hline $15: 52$ & 90.49 & 10.619 & -- \\
\hline $15: 53: 19$ & -- & -- & $1,773,000$ \\
\hline $15: 54$ & 90.49 & 10.619 & -- \\
\hline $15: 57$ & 90.492 & 10.617 & -- \\
\hline $16: 00$ & 90.488 & 10.621 & -- \\
\hline $16: 04$ & 90.491 & 10.618 & -- \\
\hline $16: 06$ & 90.492 & 10.617 & -- \\
\hline $16: 09$ & 90.49 & 10.619 & -- \\
\hline $16: 14$ & 90.492 & 10.617 & -- \\
\hline $16: 16: 37$ & -- & -- & $1,786,000$ \\
\hline $16: 17$ & 90.488 & 10.621 & -- \\
\hline \multicolumn{4}{|c|}{ pumping rate adjusted from $16: 20-16: 32$} \\
\hline $16: 33$ & 90.55 & 10.559 & -- \\
\hline $16: 35: 56$ & -- & -- & $1,797,000$ \\
\hline $16: 37$ & 90.55 & 10.559 & -- \\
\hline $16: 40$ & 90.55 & 10.559 & - \\
\hline $16: 43$ & 90.552 & 10.557 & -- \\
\hline $16: 45$ & 90.552 & 10.557 & -- \\
\hline $16: 48$ & 90.551 & 10.558 & -- \\
\hline $16: 51$ & 90.551 & 10.558 & -- \\
\hline $16: 54$ & 90.55 & 10.559 & -- \\
\hline $16: 56$ & 90.55 & 10.559 & -- \\
\hline $16: 58$ & 90.55 & 10.559 & -- \\
\hline $16: 58: 51$ & -- & -- & $1,810,300$ \\
\hline \multicolumn{4}{|c|}{ pumping rate adjusted at $16: 59$} \\
\hline $17: 01$ & 90.65 & 10.459 & - \\
\hline $17: 03$ & 90.643 & 10.466 & -- \\
\hline $17: 04: 57$ & -- & - & $1,814,000$ \\
\hline $17: 05$ & 90.645 & 10.464 & -- \\
\hline $17: 07$ & 90.64 & 10.469 & -- \\
\hline $17: 09$ & 90.642 & 10.467 & -- \\
\hline $17: 11$ & 90.645 & 10.464 & -- \\
\hline $17: 14$ & 90.64 & 10.469 & -- \\
\hline $17: 16$ & 90.635 & 10.474 & -- \\
\hline $17: 18$ & 90.638 & 10.471 & -- \\
\hline $17: 20$ & 90.635 & 10.474 & -- \\
\hline $17: 22$ & 90.641 & 10.468 & -- \\
\hline $17: 24$ & 90.66 & 10.449 & - \\
\hline $17: 26$ & 90.65 & 10.459 & - \\
\hline $17: 27: 48$ & -- & - & $1,828,000$ \\
\hline
\end{tabular}




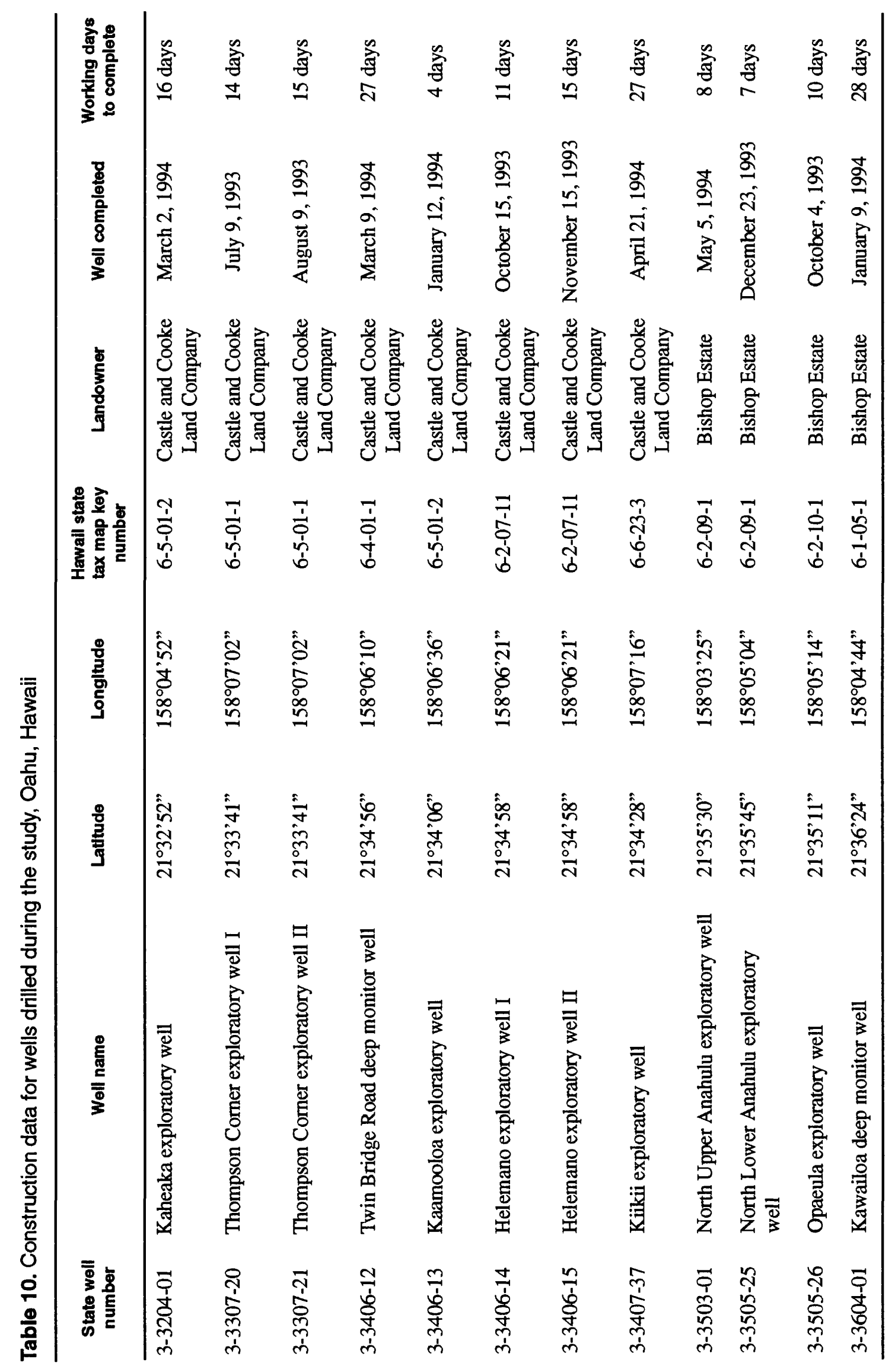




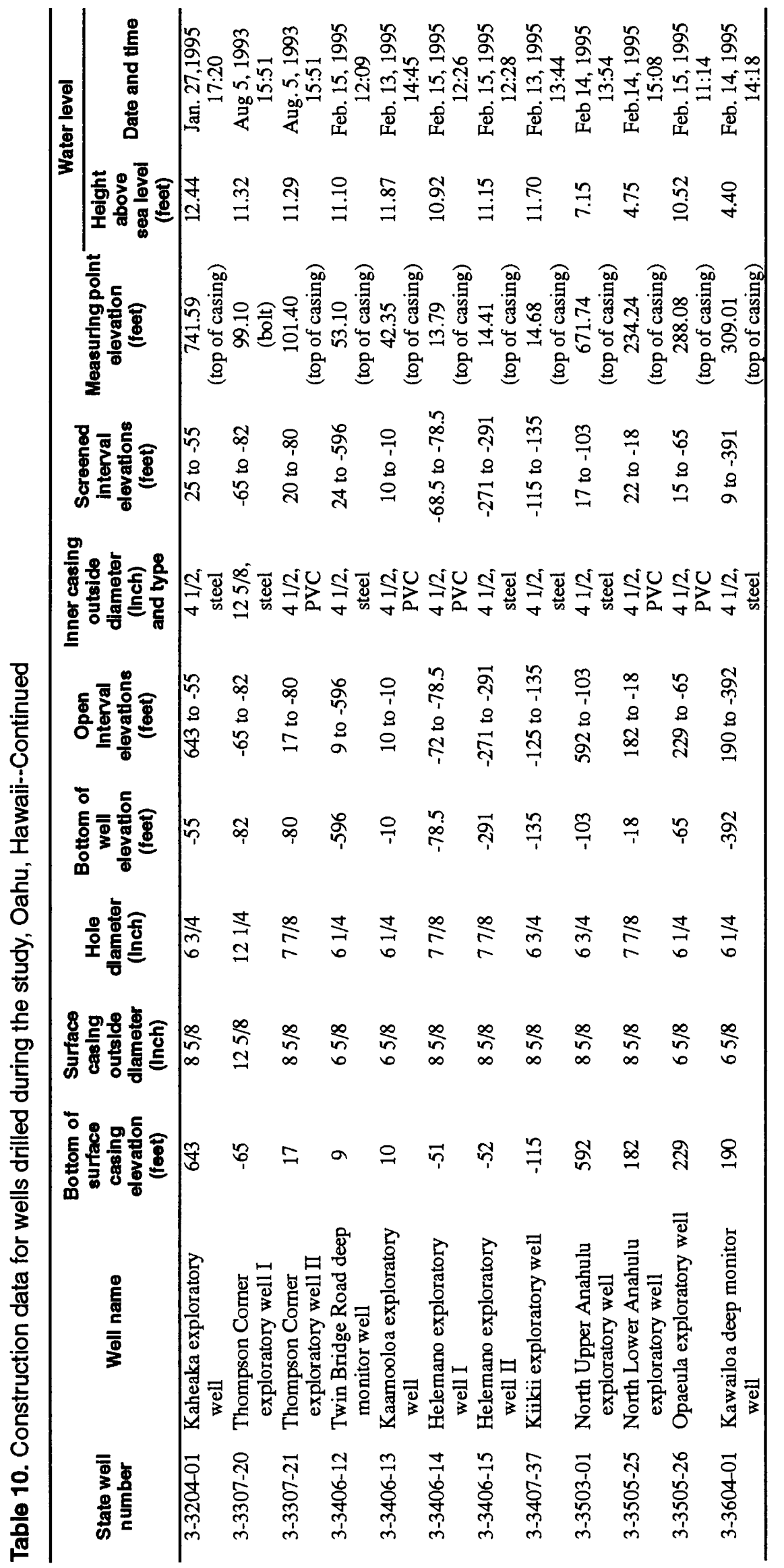

